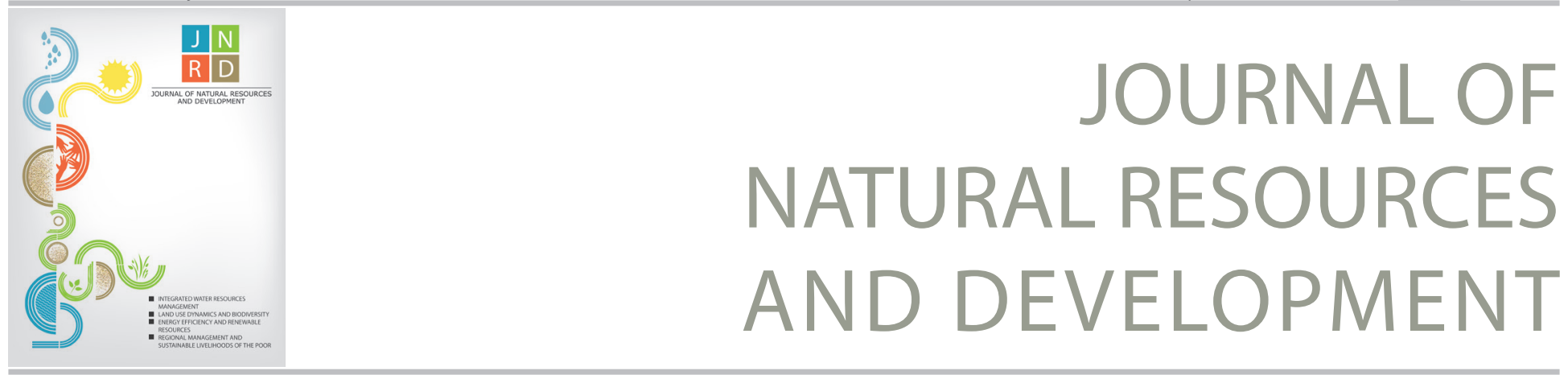

Research article

\title{
Carbon Storage of Wooden Houses, Trees, and Grazing Land in Rural Areas of Enemorina Ener District, Southern Ethiopia
}

\author{
Miftah Fekadu *ab, Tsegaye Bekele ${ }^{a}$, Sisay Feleke ${ }^{c}$ \\ Hawassa University, WGCFNR, P.O. Box: 128 Shashemene, Ethiopia \\ Central Ethiopia Environment and Forest Research Center, P.O. Box: 30708, Addis Ababa, Ethiopia \\ Wood Technology Research Center, P.O. Box: 2322, Addis Ababa, Ethiopia
}

Corresponding author: mfkedir@gmail.com

\section{Article history}

Received 05/11/2018

Accepted 18/06/2019

Published 20/08/2019

\section{Keywords}

Carbon stock

Corrugated iron sheet cover

Grass cover

Houses

Landuses

Trees

\section{Abstract}

In Ethiopia, wood was the main construction material for rural houses. In 2013, about $79 \%$ of the rural houses of Ethiopia were fully made of wood. Although carbon storage of wood is well known for climate change mitigation, there is lack of information on carbon stock of wooden houses in Ethiopia. Thus, a study was conducted to analyze the carbon stock of dominant land uses that surround rural wooden houses in three agro-ecologies and representative three peasant associations (PA) or Kebeles in Southern Ethiopia. Field measurement and household survey were made by selecting sixty-four houses made of wood, grass or corrugated iron sheet. Transects were laid starting from the wooden houses to lay out plots to collect samples of wood, grass, soot inside houses, soil and trees for carbon determination. The service age of wooden houses was estimated in triangulated interview as 5-150 years. The total carbon stock of newly constructed rural grass covered wooden house was 28.35$49.26 \mathrm{~kg} \mathrm{C} \mathrm{m}^{-2}$, which was greater than the other surrounding land uses. The grazing land total carbon stock was $50.5-86.8 \%$ and the scattered trees carbon was $9.5-59.7 \%$ of the total carbon stock of the respective PA grass covered wooden house. Since soil is the common below ground carbon stock, the total carbon of a land use is mostly affected by the above ground carbon stock. Grass covered houses contained greater above ground carbon stock but grazinglands contained greater below ground carbon stock. Soot accumulation of $0.4-1.3 \mathrm{~g} \mathrm{~m}^{-2}$ inside the houses' roof indicated the presence of indoor pollution. The total carbon stock increased with increasing altitude and geoclimatic variables were significantly correlated with carbon stock of the land uses $(p<0.05 ; r= \pm 0.999)$. Therefore, wooden houses need to be considered in climate change mitigations. The shift of carbon stock from natural environment to wooden houses in human dominated landscapes was indicator of a lack of forests, and then efforts should be strengthened to increase forest cover.

(C) 2019 This is an open access article under the CC BY-NC-ND license (http://creativecommons.org/licenses/bync-nd/4.0/). 


\section{Introduction}

Carbon storage in terrestrial carbon sinks like trees, harvested wood products and soils for longer periods of time mitigates climate change (Sheikh \& Pandit, 2014). In the carbon cycles (IPCC, 2014), soils are the major stores of carbon in terrestrial ecosystems depending on climate, soil bulk density, and soil depth (Laganière, Angers, \& Paré, 2010; Li, Niu, \& Luo, 2012). Forests store about $86 \%$ of the terrestrial aboveground carbon and $73 \%$ of the earth's soil carbon (Yin et al., 2012). Presence of forests also affect soil carbon (Chang et al., 2011; Deng et al., 2013; IPCC, 2014; Lange et al., 2015; Li, Niu, \& Luo, 2012) and other environmental carbon pools in living and dead biomass (IPCC, 2006; Iticha, 2017; Vashum \& Jayakumar, 2012). Plant biomass organic carbon vary among the branch, stem and roots of a species, growth stage, topography and site characteristics (Chen et al., 2015; Martin, Doraisami, \& Thomas, 2018; Shankar et al., 2014; Sileshi, 2014; Zhang, Guan, \& Song, 2012). For example, the carbon content of trees in softwood and hardwood usually is in leafy crown $16.8 \%$ and $24.4 \%$; debarked $\log 51.2 \%$ and $46.4 \%$; bark $10 \%$ and $6 \%$; stump $2 \%$ and $3 \%$; and roots $20 \%$ each, respectively (Potter \& Woodrom, 2017). Changing forest land use into grass land and agricultural ecosystems reduces soil organic carbon stock by $12-30 \%$ (Don, Schumacher, \& Freibauer, 2010). Global Forest Resources Assessment in 2010 estimated that the world's forests store more than $650 \mathrm{Gt} \mathrm{C}$. Moreover, the global forests ecosystems including soils store about $4500 \mathrm{Gt} \mathrm{CO}_{2}$ and land use change and forest land degradation are sources of $20 \%$ of the global greenhouse gas (GHG) emission (IPCC, 2007).

Rural wooden houses entirely constructed from woody and nonwoody biomass store carbon as coal, charcoal and wood (Zeng et al., 2013). That is promoting long-lived forest products in wood-framed buildings store carbon (llyas, 2013). For instance, the carbon density of urban settlement with wood is $23-42 \mathrm{~kg} \mathrm{C} \mathrm{m}^{-2}$ (Churkina, Brown, \& Keoleian, 2010) which is higher than the $4-25 \mathrm{Kg} \mathrm{C} \mathrm{m}^{-2}$ of tropical rain forest (Baccini et al., 2012; Pan et al., 2011). The carbon pools in wooden houses are harvested wood and grass called dead wood and grass, which could be sound, intermediate and rotten biomass (Casarim \& Grais, 2013). In Ethiopia, 79.8\% of the total population, or over 84.4 million people lived in rural areas in 2017 (UN DESA, 2017) and wood was the main construction material in 2013 fully in $79 \%$ of rural houses and with stone incorporation in $21 \%$ of the houses (Central Statistical Agency and World Bank, 2013).

The roof of the houses is covered either by grass or corrugated iron sheet, so are called wooden houses. The grass roofed houses have a traditional thatched-grass, conical roof with circular floor and wall, while the corrugated iron sheet covered houses have rectangular floor and wall but triangular and trapezoidal roof (Alemayehu, 2011). Moreover, rural households use biomass for cooking and heating that form soot (IPCC, 2014). This soot carbon stored in rural houses exhibited indoor pollution (Kankaria, Nongkynrih, \& Gupta, 2014).

Understanding the variability of carbon in co-occurring and adjoining land uses in rural settings like scatted trees, woodlands, wooden houses and grazing lands would enable to support the process of reducing emission and the sustainable management of natural resources (Svob, Arroyo-Mora, \& Kalacska, 2014). In Ethiopia, forest resources stored about $2.76 \mathrm{Gt} C$ in the above ground biomass (Moges, Eshetu, \& Nune, 2010) and soils stored about 14 Gt C (Shiferaw, Hurni, \& Zeleke, 2013), however, there is lack of information on the carbon content of individual tree species and the carbon stock of rural wooden houses. Accordingly, it is important to understand the dynamics of carbon sinks in and around human dominated landscapes of rural wooden house settlements in order to design strategies that improve the carbon storage (Western Australian Planning Commission, 2013). Therefore, this study was conducted to address the aforementioned problems with the objective to determine the carbon stock of wooden houses in comparison to surrounding scattered trees and grazing land uses by identifying the types of woody plant species that were used for wooden house construction.

\section{Material and Methods}

\subsection{Description of the study area}

The study was conducted in Southern Ethiopia, Enemorina Ener district's three peasant associations (PA) now called Kebele (Awed, Daemir and Ener Kola). The three PAs each were representatives of three different agro-ecologies called highland, midland and lowland at 500-1600 m, 1600-2400 m and 2400-3200 m altitude above sea level (asl), respectively (Figure 1). The rural people of the study area had subsistence agriculture, a kind of mixed farming and depend on local vegetation for fuel and construction. Eucalyptus globulus Labill. poles in highland; E. camaldulensis Dehnh. poles in midland; and Cordia africana Lam. lumber and charcoal making in the agro pastoral lowland were the main tree products cash sources. Each PA covers an area over 800 ha, part of which may fall in different agroecology at a given altitudinal range, for example in 500-1600 m asl, $1516 \mathrm{~m}$ was specifically sampled (Table 1 ).

The soils of the study area were free of gravel except close to river sides and degraded areas. The highland had rugged topography with ferric sandy loam soils (Table 1). The district was also described by Negussie (2004) and the precipitation and temperature is given in Figure 2.

In 2005-2013, the mean monthly precipitation in Enemorina Ener district, capital town, Gunchire was 21.65-266.5 mm, with annual mean of $1290 \mathrm{~mm}$ as indicated in the Ethiopia Meteorological data, but in lowlands 900, midland 1150 and highlands $1400 \mathrm{~mm}$ was conventionally known on average (Bekele-Tesema, 2007). The main rainy season is June to September. In 2005-2013, the neighboring district's maximum monthly temperature was $21.7-26.8{ }^{\circ} \mathrm{C}$ and minimum temperature was $6.7-11.9{ }^{\circ} \mathrm{C}$ (Figure 2) but in lowlands 24.25, in midland 18.5 and in highlands $13.5^{\circ} \mathrm{C}$ was conventionally known on average (Bekele-Tesema, 2007). 


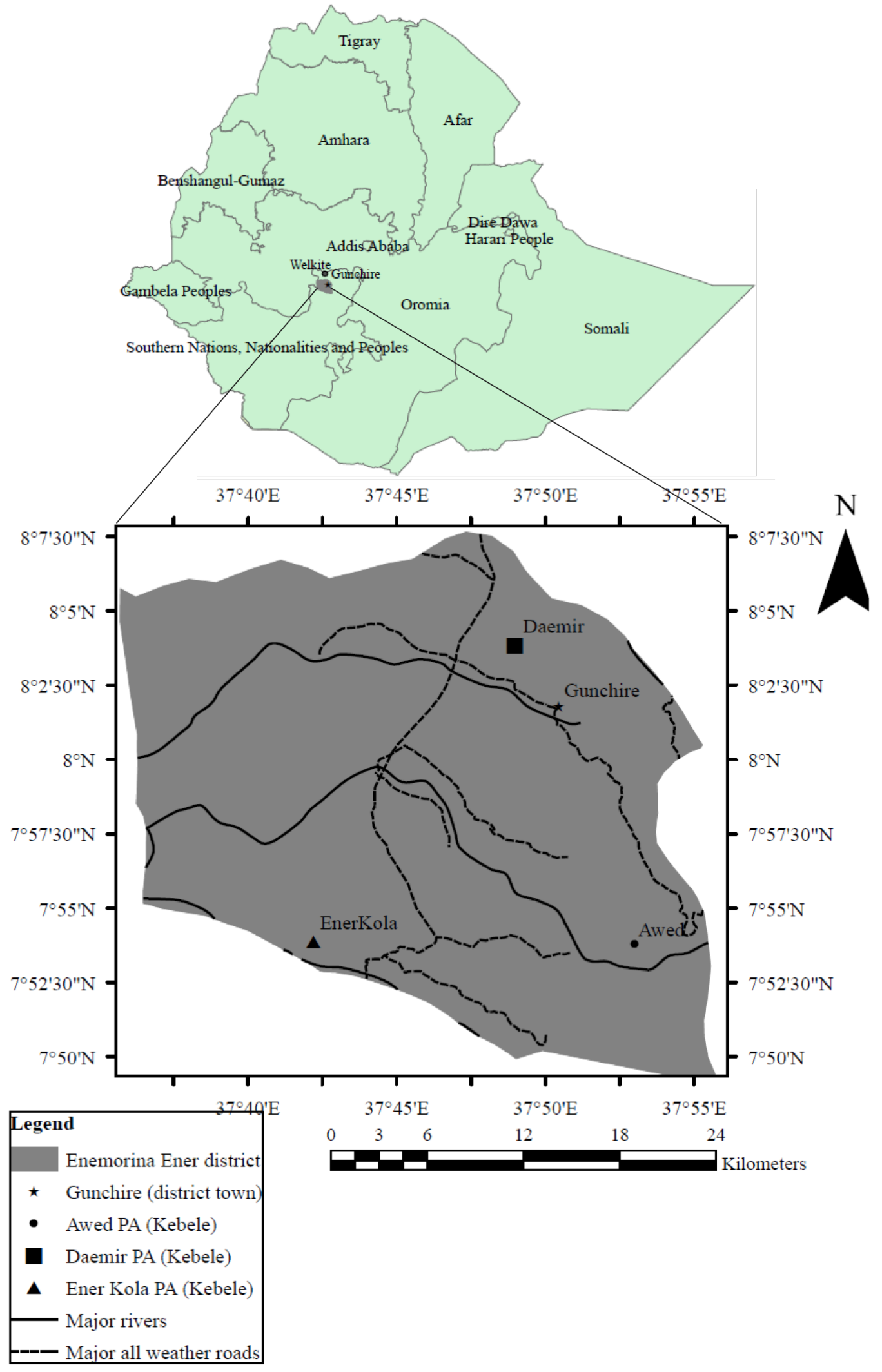

Figure 1: Location map of the study area. (The scale of the map refers only to the three peasant associations or Kebeles and their surroundings). 
Table 1: Geographic and climatic conditions of studied peasant associations (Kebeles)

\begin{tabular}{|c|c|c|c|c|c|c|c|c|c|}
\hline $\begin{array}{c}\text { Peasant asso- } \\
\text { ciation/agro- } \\
\text { ecology }\end{array}$ & $\begin{array}{c}\text { Agroclimatic } \\
\text { category and } \\
\text { terrain* }\end{array}$ & $\begin{array}{l}\text { Altitude } \\
\text { asl (m) }\end{array}$ & Latitude & Longitude & $\begin{array}{c}\text { General } \\
\text { mean annual } \\
\text { Rainfall } \\
(\mathrm{mm})\end{array}$ & $\begin{array}{c}\text { General mean } \\
\text { annual } \\
\text { temperature } \\
\left({ }^{\circ} \mathrm{C}\right)\end{array}$ & $\begin{array}{c}\text { Dominant woody } \\
\text { vegetation }\end{array}$ & $\begin{array}{c}\text { Total } \\
\text { houses }\end{array}$ & $\begin{array}{c}\text { Stan- } \\
\text { dard } \\
\text { houses }\end{array}$ \\
\hline $\begin{array}{c}\text { Awed/ } \\
\text { Highland }\end{array}$ & $\begin{array}{l}\text { Cold to very } \\
\text { cold moist } \\
\text { mountains- } \\
\text { rugged terrain }\end{array}$ & 2480 & $7^{\circ} 53^{\prime} 54.7^{\prime \prime}$ & $37^{\circ} 53^{\prime} 12.4^{\prime \prime}$ & 1400 & 13.5 & $\begin{array}{c}\text { Eucalyptus globulus Labill. } \\
\text { Juniperus procera Hochst. } \\
\text { ex Endl. } \\
\text { Ficus sur Forssk. and Yus- } \\
\text { hania alpina (K. Schum.) } \\
\text { W.C.Lin }\end{array}$ & 846 & 77 \\
\hline $\begin{array}{l}\text { Daemir/Mid- } \\
\text { land }\end{array}$ & $\begin{array}{c}\text { Tepid to cool } \\
\text { submoist - } \\
\text { plains }\end{array}$ & 2004 & $8^{\circ} 4^{\prime} 1.8^{\prime \prime}$ & $37^{\circ} 48^{\prime} 53^{\prime \prime}$ & 1150 & 18.5 & $\begin{array}{l}\text { Acacia abyssinica Hochst. ex } \\
\text { Benth, Eucalyptus camaldu- } \\
\text { lensis Dehnh., Juniperus pro- } \\
\text { cera Hochst. ex Endl., Olea } \\
\text { species, Phoenix reclinata } \\
\text { Jacq., Podocarpus falcatus } \\
\text { (Thunb.) R.Br. ex Mirb., Syzy- } \\
\text { gium guineensis Willd. DC., } \\
\text { Bersama abyssinica Fresen., } \\
\text { and Croton macrostachyus } \\
\text { Hochst. ex Delile. }\end{array}$ & 276 & 117 \\
\hline $\begin{array}{c}\text { Ener Kola/ } \\
\text { Lowland }\end{array}$ & $\begin{array}{l}\text { Hot to warm } \\
\text { semiarid- } \\
\text { plains\& } \\
\text { valleys }\end{array}$ & 1516 & $7^{\circ} 54^{\prime} 15.4^{\prime \prime}$ & $37^{\circ} 42^{\prime} 10^{\prime \prime}$ & 900 & 27.5 & $\begin{array}{l}\text { Acacia albida (syn. Faidher- } \\
\text { bia albida) (Delile) A. Chev., } \\
\text { Acacia seyal Delile, A. tortilis } \\
\text { (Forssk.) Hayne, Balanitus } \\
\text { sps., Combretum sps., Euclea } \\
\text { schimperi (A.DC.) Dandy and } \\
\text { Acokanthera schimperi } \\
\text { (A.DC.) Schweinf., Cordia } \\
\text { africana Lam. }\end{array}$ & 245 & 20 \\
\hline
\end{tabular}

*Source: Bekele-Tesema (2007) and own GPS readings; asl =above sea level.

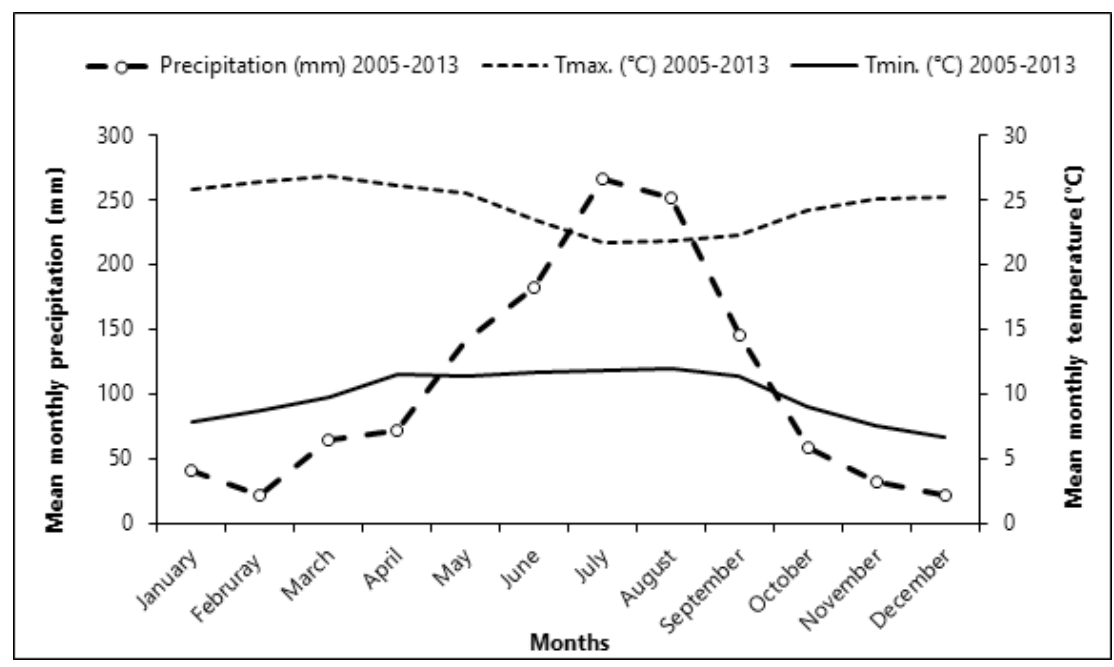

Figure 2: Mean monthly precipitation and temperature (2005-2013) of the studied district capital, Gunchire. (The temperature is from neighboring district in 2005-2013). 


\subsection{Methods of data collection and analyses}

The study area was selected based on discussion at district level by considering the differences in the altitudinal range that affect the agro-ecology and availability of different plant species (Sheikh, Kumar, \& Bussmann, 2009). Each PA was selected to represent an agro-ecology. In each PA, stratified random sampling was used to select houses, in two steps. First, houses with common internal and external wood structures, called standard wooden houses that were covered their roof with grass or corrugated iron sheet were assessed and selected. The nonstandard houses built from crop residues like maize stalks and grass were exclude from the study. Secondly, 30\% of the standard wooden houses were randomly selected (Bryman, 2012). At the selected PA's specific altitude 23,35 and 6 houses (Table 1) were selected, interviewed and measured in Awed PA; Daemir PA; and Ener Kola PA, respectively. Totally, 64 households' heads, both men and women, were selected and convinced to voluntarily participate in the activities after explaining the purpose of the research. The house owners were interviewed about the age of house (month and year of construction), the type of tree species used for each part of the house, the number of wood used for different parts of the house, and the size of the house. Then the interview results were validated by visual observation, counting, triangulated interview of local elders, Kebele officials and house constructors (engineers) who construct the house. The dimensions were measured using graduated poles and measuring tape.

Land uses around the wooden houses were many but carbon stock was determined for three dominant landuses that occupy most of the area and available to all households including grazing land, scattered live trees, or wood lands (scattered trees in patches and plantations) and wooden houses.

\subsubsection{Wooden houses and construction wood sampling and analyses}

Wooden houses and wood were measured depending on the geometric shape. The circular grass covered houses diameter and the rectangular corrugated iron sheet covered houses perimeter (length and width) were measured at the flat ground (water level) of the houses using measuring tape. The area of grass covered wooden houses was determined using Equation 1 (West, 2015).

$A_{1}=\frac{\pi\left(D^{2}\right)}{4}$

Equation 1

Where: $A 1$ : area of circular grass covered wooden house $\left(\mathrm{cm}^{2}\right) ; \pi$ is a constant value 3.142 and $D$ is the internal diameter of the circular grass covered house $(\mathrm{cm})$ (Figure $3 \mathrm{a}$ ).

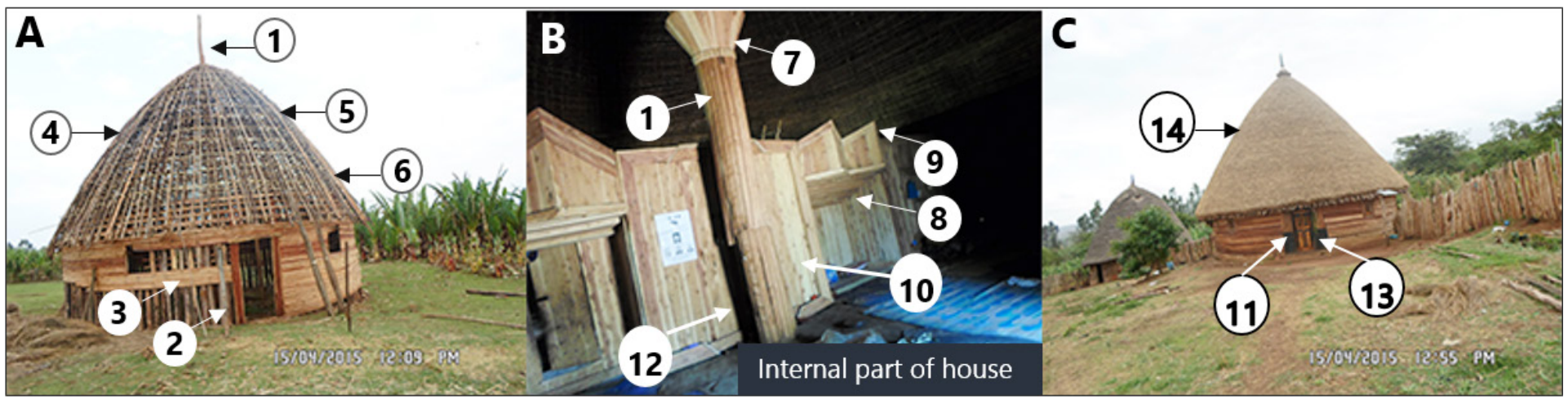

Figure 3: External and internal parts of rural grass covered wooden house.

Table 2: Parts of rural grass covered wooden house using different types of wood

\begin{tabular}{|l|l|l|} 
*No & \multicolumn{1}{|c|}{ Names and description of parts of grass covered wooden houses } & \multicolumn{1}{|c|}{ Type of wood used } \\
\hline 1 & $\begin{array}{l}\text { Central axis, central supporting post (Miseso) inserted } 1 \mathrm{~m} \text { to below } \\
\text { ground and aerially extends outside above the house about } 1.5 \mathrm{~m} \text {. It is a } \\
\text { framework for the support of lateral extension of the roof. }\end{array}$ & $\begin{array}{l}\text { Single round wood which is the strongest, and biggest in diameter and } \\
\text { height. }\end{array}$ \\
\hline 2 & $\begin{array}{l}\text { Surrounding wall making circle, vertically, (quami gidgida) of the house } \\
\text { inserted } 50 \mathrm{~cm} \text { below ground. }\end{array}$ & Split wood from bigger diameter trees locally called "gordera". \\
\hline 3 & Horizontal fastener of vertical wall. & Thin and long split wood poles \& posts. \\
\hline
\end{tabular}


Table 2: (continued)

\begin{tabular}{|c|c|c|}
\hline *No & Names and description of parts of grass covered wooden houses & Type of wood used \\
\hline 4 & $\begin{array}{l}\text { Roof or crown arc post from central axis to wall top-vertically consisting } \\
\text { primary, secondary and tertiary posts axis to wall top. }\end{array}$ & Round wood of relatively thin, long poles and posts. \\
\hline 5 & Horizontal fastener and circling posts in roof or crown. & Split or round wood of relatively thin and long poles. \\
\hline 6 & Kava: (Zaana) placed vertically put between the posts in number 4 . & Split, short and light wood. \\
\hline 7 & $\begin{array}{l}\text { Zogire: in internal side of roof that base and extend from the upper part } \\
\text { of the surrounding of central axis and support the roof vertically. }\end{array}$ & $\begin{array}{l}\text { Round or split wood which are longer in height but thinner than the } \\
\text { vertical walls. }\end{array}$ \\
\hline 8 & Natere: livestock like cattle fastener. & Round wood used for fastening livestock. \\
\hline 9 & $\begin{array}{l}\text { Qot: internal shelf as horizontal roof partition to place tools and equip- } \\
\text { ment and residing chickens placed on top of natere (8). }\end{array}$ & Mixture of round and split wood. \\
\hline 10 & $\begin{array}{l}\text { Guada: internal vertical floor partition to store tools } \& \text { utensils like box } \\
\text { and bed or reside livestock. }\end{array}$ & Usually made of sawn wood (lumber). \\
\hline 11 & Door and windows to close partitions or ventilation. & Usually made of lumber. \\
\hline 12 & Chair is used for sitting and made locally. & Made from Cordia africana or Ficus sur. \\
\hline 13 & Atrashe: Vertical walls on both sides of door. & Bigger sized split wood in vertical wall. \\
\hline 14 & Grass covering the house roof. & Grass obtained from fenced grazing/grass lands. \\
\hline
\end{tabular}

* List of numbers referred in Figure 3.

The area of corrugated ironsheet covered rural wooden houses (Figure 4) was determined using Equation 2 (West, 2015).

$A_{2}=L W$

Equation 2

Where: $A_{2}$ : area of corrugated iron sheet covered wooden house $\left(\mathrm{cm}^{2}\right) ; L$ is length $(\mathrm{cm})$ and $W$ is width of rectangular house $(\mathrm{cm})$.

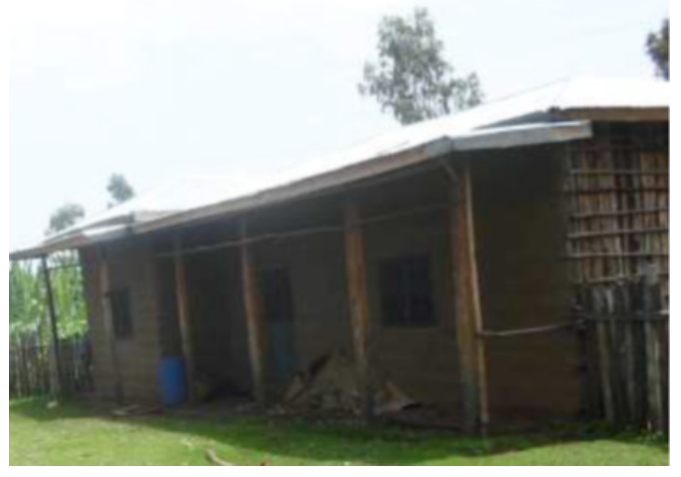

Figure 4: Wooden house covered with corrugated ironsheet.
The length, diameter, thickness and width of all the dead wood contained in a house, based on shape of wood, was measured using measuring tape and graduated pole. In straight, round wood, diameter at midpoint and total length but in regularly split wood like lumber, length $(L)$, width $(W)$ and thickness $(T)$ at midpoint was measured and its volume was calculated as Equation 3.

$\mathrm{V}=\mathrm{LWT}$

Equation 3

Where: $V$ : volume of wood $\left(\mathrm{cm}^{3}\right), L$ is length $(\mathrm{cm}), W$ is width $(\mathrm{cm})$ and $T$ is thickness (cm).

In all types of dry or dead wood used for house construction, three replications of representative wood samples were taken to determine full weight using balance (Adam Lab.equipment Leicester LE67FTEngland $0.1 \mathrm{~g}$ ). The volume of round wood, split wood (Figure 5), and lumber like wood (immersed in water for 24 hours) was calculated using Huber formula (Waddell, 1989; West, 2015) and the volume of lumbers added to give the full log volume (Cruz de León \& UrangaValencia, 2013) (Equation 3 and Equation 4) to get the mass from basic density. 
$V=\frac{\pi\left(D^{2}\right)}{4} L$

Equation 4

Where: $V$ : volume of $\log \left(\mathrm{cm}^{3}\right) ; \pi$ is a constant value $3.142, D$ is mid diameter $(\mathrm{cm})$ and $L$ is the length of $\log (\mathrm{cm})$.

Basic wood density for dry wood and household utensils, called dead wood (Casarim \& Grais, 2013), was determined by the ratio of oven dried $\left(105^{\circ} \mathrm{C}\right)$ weight to green volume. Smaller household utensils such as local chair and lumbers for house partitioning were considered as the houses carbon storage structures and the density was determined from a fraction of the lumber used to make the utensils. Then green volume of small samples was determined by water displacement method (immersed in water for 24 hours) (Govett, Mace, \& Bowe, 2010; Williamson \& Wiemann, 2010) using distilled water and graduated cylinder. The three replications of small samples for basic wood density were straight, undamaged, nonporous, debarked or undebarked, knot-free, $20-25 \mathrm{~mm}$ thick and $25 \mathrm{~cm}$ long dry wood taken at midpoint of the wood used for construction. In the case of below ground dead wood about $1 \mathrm{~m}$ of the central axis, and $50 \mathrm{~cm}$ of the surrounding wall, three representative samples from each species (dug out, cleaned and immersed in water for 24 hours) were measured for basic density. Any rooten wood part from samples was removed before measurement. The wood samples for basic density were in ranges of 1-150 years old, which were grouped in to five years, 30 samples, sample 1 for $1-5$ years, sample 2 for 6-10 years and sample 3 for 11-15 years etc. Carbon stock in the sampled wood was determined using mass or basic density and volume, and carbon concentration of wood (Krajnc, 2015). For over bark measured wood, sample wood carbon with bark was used. The basic density and carbon content of wood were kept constant for a given part of a tree species.

The total weight of grass used in grass covered wooden house was obtained stepwise; first, the number of manloads of grass used per house was interviewed to selected men and women house owners and checked by counting. Manload is a local measurement unit of weight that can be carried by a matured person. Then three to five samples of manload of airdried grass were weighed using weighing balance (Adam Lab.equipment Leicester LE67FT-England, $0.1 \mathrm{~g}$ ) in each PA study site to get the average weight of a manload of grass. Oven dry weight $\left(105^{\circ} \mathrm{C}\right)$ of each manload was determined from samples, and then the total dry weight of the grass of the house was extrapolated.

\subsubsection{Soot of wooden houses sampling and analyses}

Soot is an indoor pollutant, black carbon, resulting from incomplete combustion of fuel. Soot was sampled by clearing all the internal parts of roofs (top part) of wooden houses (Figure $3 \mathrm{~b}$ and Table 2, No 4). Soot samples were collected from 13 houses covered with grass and 6 houses covered with corrugated iron sheet of volunteer households using brooms. The samples were collected every 4 months and weighed using a balance (Adam Lab. Equip. Leicester LE67FT-England, $0.001 \mathrm{~g}$ ). It was observed as a usual practice that rural households clear the soot from the internal roof of wooden houses during holidays in the study area twice to three times per year.

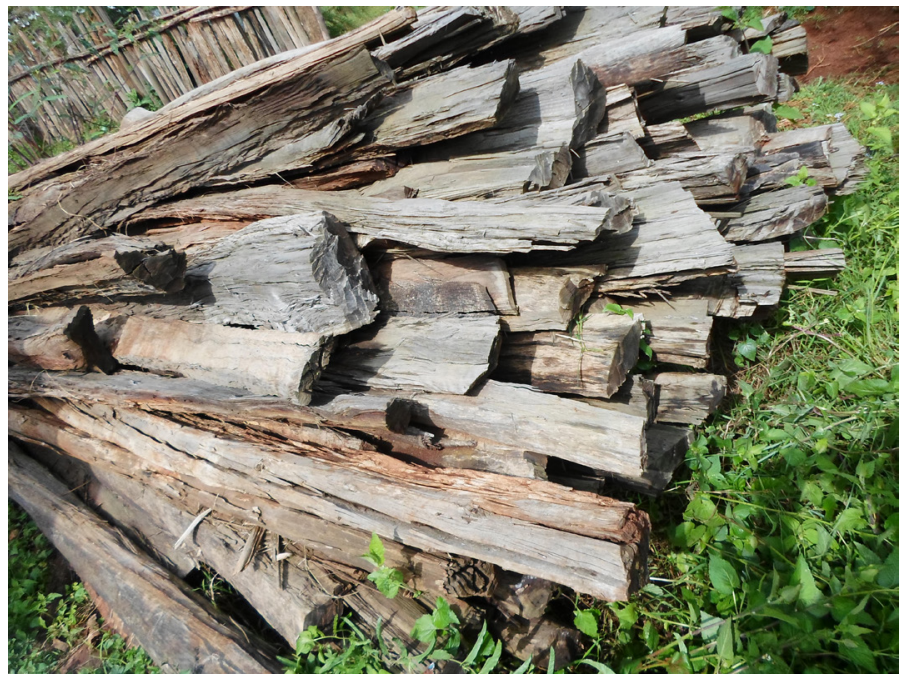

Figure 5: The surrounding wall split wood for wooden house construction.

\subsubsection{Grazing land sampling and analyses}

In grazing land, grass and soil samples were taken in three representative pits and plots, respectively; within $1 \mathrm{~km}$ three replications of transects from the houses, at 300-400 m distance between transects and plots (Figure 6). The first plot was determined systematically, where grasses exist at 300-400 m distance from the houses.

Soil pit about $1 \mathrm{~m} \times 1 \mathrm{~m} \times 1 \mathrm{~m}$ was dug and soil samples were collected at vertical profile of five soil depths $0-5 \mathrm{~cm}, 5-15 \mathrm{~cm}, 15-30 \mathrm{~cm}, 30-50$ $\mathrm{cm}$ and $50-100 \mathrm{~cm}$. In each soil depth three cores were sampled as a replication for the depth in dry season, March-April 2015.

The soil bulk density (Equation 5) was determined as the ratio of oven dried weight to core volume (5 cm cube) (Equation 6) (Makhuvha, Arellano, \& Harney, 2014). Live grass samples were collected at $1 \mathrm{~m}$ x $1 \mathrm{~m}$ above each soil pit, oven dried $\left(105^{\circ} \mathrm{C}\right)$ and weighed using balance (Adam Lab.equipment Leicester LE67FT-England, $0.001 \mathrm{~g}$ ).

$B D=\frac{M}{V}$

Equation 5

Where: $B D$ : bulk density of soil $\left(\mathrm{g} \mathrm{cm}^{-3}\right) ; M$ is mass of oven dried soil sample $(\mathrm{g})$ and $V$ is volume of soil sample corer $\left(\mathrm{cm}^{3}\right)$.

The volume of soil sample corer was determined by Equation 6 .

$V=\frac{\pi D^{2}}{4} \underline{H}$ Equation 6

Where: $V$ : volume of soil sample corer $\left(\mathrm{cm}^{3}\right)$; $D$ is core diameter $(\mathrm{cm})$ and $H$ is the height of corer $(\mathrm{cm})$. 

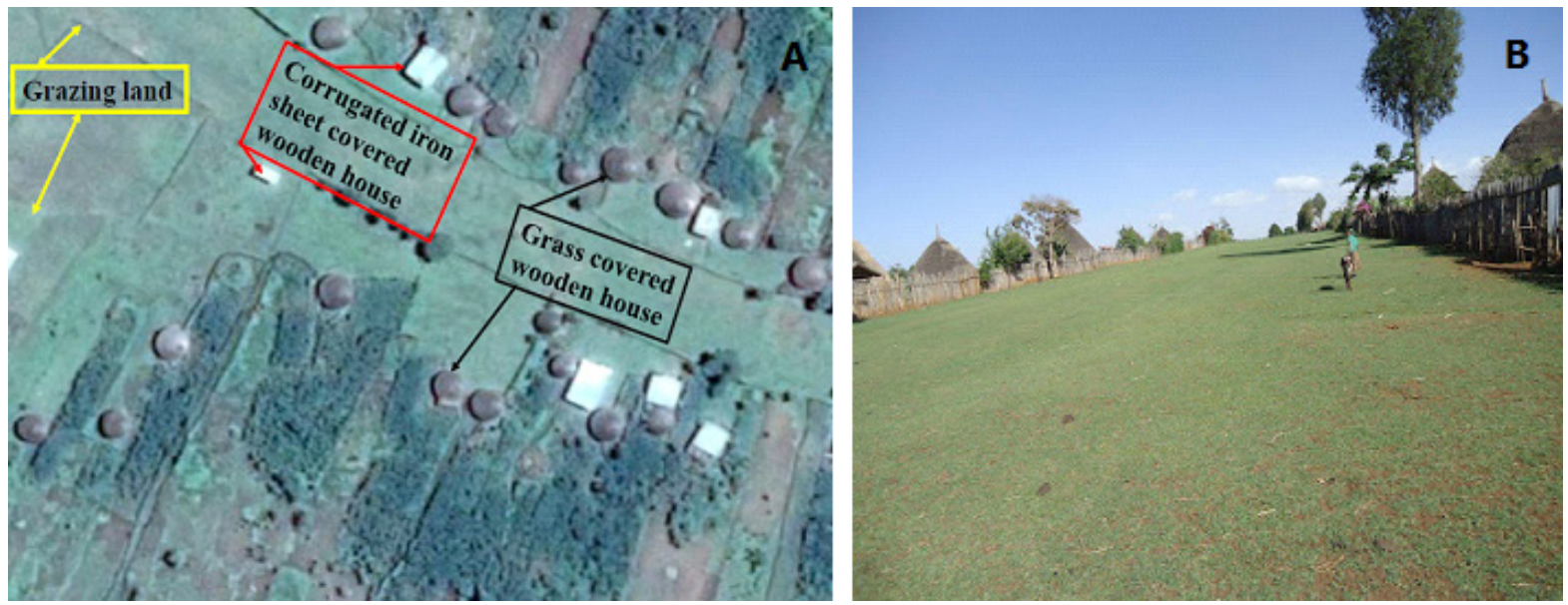

Figure 6a, 6b: Sampling transect for grazing land and scattered trees. Fig. 6a depicts topview of different landuses surrounding the rural wooden houses, Fig. 6b displays the sidewise arrangement of rural wooden houses (source: Google Earth).

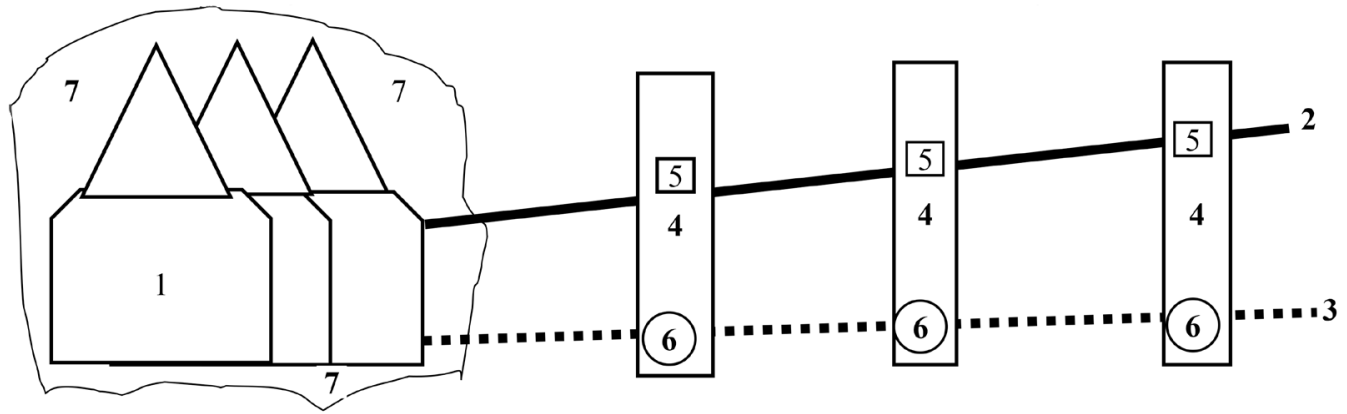

1. Rural wooden houses

2. Transect of $1 \mathrm{~km}$ for soil sampling pit excavation

3. Transect of $1 \mathrm{~km}$ for standing woody vegetation

forest and woodland sampling plot establishment

4. Alignment for grazing land soil sample and woody vegetation plot
5. Soil sample excavation pit and grass sampled point

6. Woody vegetation sampled plot

7. Home gardens

Figure 6c: Sampling transect for grazing land and scattered trees, $6 \mathrm{c}$ shows sampling design of trasect lines made in the field.

\subsubsection{Scattered, standing live trees sampling and analyses}

Scattered, standing live trees sampling was done in the same way as section 2.2.3. The first plot was determined systematically, where woody plants exist at 300-400 m distance from the houses. The standing volume of scattered live trees (UNFCCC, 2001) with height $\geq 2 \mathrm{~m}$ and diametre $\geq 5 \mathrm{~cm}$ was estimated using diameter at breast height (DBH) (1.3 $\mathrm{m}$ from the ground surface) and total height measured (Government of Alberta, 2012) using diameter tape and graduated pole, respectively, in 3-5 plots of 5.64 m radius in each PA. Three to 11 trees /shrubs of selected species used for house construction were cut to measure their above ground biomass and stem form factor (Equation 7 and Equation 8), moisture content (Equation 9), carbon content and wood density.

$$
\mathrm{ff}=\frac{\sum_{i=1}^{n} \mathrm{v}_{\mathrm{i}}, \mathrm{n}}{\mathrm{v}_{\mathrm{c}}}
$$

Where: ff. form factor, $V_{\mathrm{i}^{\prime}} \mathrm{n}$ is the volume $\left(\mathrm{cm}^{3}\right)$ of cut logs from the first log: $i=1$ to the last log $=\mathrm{n}$ of close to $100 \mathrm{~cm}$ length as:

$V_{1}=\pi\left(D_{1}\right)^{2} / 4 ; V_{2}=\pi\left(D_{2}\right)^{2} / 4 \ldots ; V_{n}=\pi\left(D_{n}\right)^{2} / 4 ; D$ is middiameter of cut logs $(\mathrm{cm}) ; V_{c}$ is the standing cylindrical volume $\left(\mathrm{cm}^{3}\right)$ of a tree as:

$\mathrm{V}_{c}=\pi\left((\mathrm{DBH})^{2} / 4\right) *(\mathrm{H}) ; D B H$ is diameter at breast height $(\mathrm{cm}) ; H$ is total height $(\mathrm{cm})$.

The volume of standing live trees were determined by Equation 8 . 
$V_{a}=\frac{\sum_{i=1}^{n}\left(f_{i j} \times V_{c i j}\right)}{n}$

Equation 8

Where: $V_{\mathrm{a}}$ : the actual volume $\left(\mathrm{cm}^{3}\right)$ of standing tree; $V_{c}$ is the cylindrical volume $\left(\mathrm{cm}^{3}\right)$ of tree; $f f$ is form factor; ij is the $i^{\text {th }}$ species and $\mathrm{j}^{\text {th }}$ replication; $n$ is replications.

$M C=\left(W_{i}-W_{f} / W_{i}\right) \times 100$

Equation 9

Where: MC: moisture content (\%); $W_{\mathrm{i}}$ is initial weight $(\mathrm{g}) ; W_{\mathrm{f}}$ is final weight $(\mathrm{g})$.

The cut trees were divided into different biomass fractions. Branches $\geq 5 \mathrm{~cm}$ diameter were added to stem and branches $<5 \mathrm{~cm}$ diameter considered as twigs and leaves. The weight of the sample wood was measured by digital balance (Adam Lab.equipment Leicester LE67FTngland $0.1 \mathrm{~g}$ ). The below ground root biomass was assumed to be $20 \%$ of the above ground. The weight of residues including leaves and barks were considered to be used as biomass energy, proportionally $24.4 \%$ and $6 \%$ of the total weight of a given tree, respectively (Potter \& Woodrom, 2017).

\subsubsection{Carbon analysis in laboratory from wood, grass, soot and soil samples}

The organic carbon content of plant materials (wood, grass and soot) was determined by repeated measures made using Walkley and Black (1934) procedures by making the weight of the ground dry sample as small as 0.125-0.5 $\mathrm{g}$ and $1 \mathrm{~mm}$ sieved because of high carbon concentration in plant cells. However, in the presence of a muffle furnace, the cheap and easy procedure of loss on ignition method that uses $5-10 \mathrm{~g}$ dry plant material sample at $400^{\circ} \mathrm{C}$ for four hours and with 0.58 factor of ash percent can be used as the carbon (Wang, Wang, \& Zhang, 2012). In determining soil organic carbon, about 1-2 $\mathrm{g}$ air dried soil sample, <2 $\mathrm{mm}$ sieved was used by Walkley and Black (1934) method. Then samples in each plant and soil were prepared separetly in flask and $10 \mathrm{ml}, 1 \mathrm{~N} \mathrm{~K}_{2} \mathrm{Cr}_{2} \mathrm{O}_{7}$ solution was added with pipette to samples $\left(\mathrm{V}_{1}\right)$ and blank $\left(\mathrm{V}_{2}\right)$ followed by addition of $20 \mathrm{ml}$ concentrated $\mathrm{H}_{2} \mathrm{SO}_{4}$. Then $200 \mathrm{ml}$ distilled water was added to cool. About $10 \mathrm{ml}$ concentrated Orthophosphoric acid was added before titration in the presence of $0.5 \mathrm{ml}$ barium diphenylamine sulphonate indicator. The sample and blank were titrated with $0.5 \mathrm{~N}$ ferrous sulfate solution drop by drop until green to light green end point. In this method $77 \%$ of the carbon was assumed to be oxidized by potassium dichromate and a correction factor of $100 / 77$ or 1.3 was used (Equation 10).

$O C=N x \frac{\left(V_{1} \times V_{2}\right)}{S} \times 0.39 \times m c f$

Equation 10

Where: OC: Organic carbon (\%); $\mathrm{N}$ is normality of $\mathrm{K}_{2} \mathrm{Cr}_{2} \mathrm{O}_{7}$ solution (mole eq- ${ }^{-1} / 1000 \mathrm{ml}$ ); $V_{1}$ is volume $(\mathrm{ml})$ of ferrous sulfate solution used for the blank; $V_{2}$ is volume $(\mathrm{ml})$ of ferrous sulfate solution used for the sample; $S$ is weight $(\mathrm{g})$ of air-dried sample; 0.39 is constant value $\left(0.39=3 \times 10^{-3} \times 100 \times 1.3\right.$ (3 is equivalent weight of carbon)) (Walkley \& Black, 1934); $m c f=$ moisture correction factor as $1+\mathrm{mc} \%$.

The total organic carbon storage of wood in houses was calculated as the sum of the carbon stocks of the different components of tree species wood (Equation 11) and grass (Equation 12) in the case of grass covered houses; and wood only in the case of corrugate iron sheet covered houses.

$C w=\frac{\sum_{i, j=1}^{n}\left(B D_{i j} x V_{i j} x O C_{i j}\right.}{n}$

Equation 11

Where: $C w$ : Carbon storage of wood (g); $B D$ is basic density of a given part of wood of a species $\left(\mathrm{g} \mathrm{cm}^{-3}\right) ; V$ is volume of a given part of wood of a given species $\left(\mathrm{cm}^{3}\right)$; OC is organic carbon content of a given part of a given species (\%); $i j$ is the $i^{\text {th }}$ species and $j^{\text {th }}$ replication; $n$ is the number of replication.

$\mathrm{Cg}=\mathrm{Mgr} \times \mathrm{OC}$

Equation 12

Where: $\mathrm{Cg}$ : carbon storage of grass ( $\mathrm{g}) ; \mathrm{Mgr}$ is mass of grass $(\mathrm{g}) ; O C$ is the organic carbon content of grass (\%).

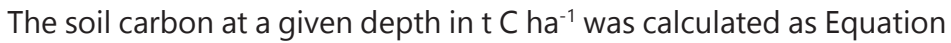
13.

$S O C s=d \times O C \times B D$

Equation 13

Where: SOCs: soil organic carbon stock $(\mathrm{t} \mathrm{C} \mathrm{ha-1)}, d$ is depth or thickness of the soil (cm), OC is organic carbon (\%), BD is bulk density $\left(\mathrm{g} \mathrm{cm}^{-3}\right.$ ) (Sanderman, Farquharson, \& Baldock, 2010).

The Pearsons correlation of landuses carbon with geo-climatic variables and wood density was calculated as Equation 14.

$\mathbf{r}=\sqrt{\frac{\left(\sum X Y-\frac{\sum X \sum Y}{n}\right)^{2}}{\left(\sum X^{2}-\frac{\left(\sum X\right)^{2}}{n}\right)\left(\sum Y^{2}-\frac{\left(\sum Y\right)^{2}}{n}\right)}}$

Equation 14

Where: $r$ : correlation coefficient, $X$ is geo-climate: altitude $(m)$; precipitation $(\mathrm{mm})$; temperature $\left({ }^{\circ} \mathrm{C}\right)$ or wood density $\left(\mathrm{g} \mathrm{cm}^{-3}\right)$ and $Y$ is the carbon storage of different land uses $(\mathrm{t} \mathrm{C} \mathrm{ha-1)}$.

\section{Results}

The carbon storage of a landuse depends on the composition of the landuse and its size. The wooden houses carbon stock varied with the type of plant species used for construction because different plant species have different carbon content.

\subsection{Major tree species used for house construction}

Two types of houses were constructed in the study area using top roof cover of either grass or corrugated iron sheet. As shown in 
Figure 7, for house construction, different tree species were used in different agro-ecologies. In highland PA, Eucalyptus globulus and Yushania alpina were dominantly used, accounting 69.7 and $18.1 \%(\mathrm{w} / \mathrm{w})$ of the wood in grass covered wooden house; and 90.9 and $6.9 \%$ of the wood in corrugated iron sheet covered house, respectively. In midland $\mathrm{PA}, E$. camladulensis was dominantly used, accounting $98.5 \%$ of the wood in grass covered house and $97.2 \%$ of the wood in corrugated iron sheet covered house. In lowland PA, Euclea schimperi and Combretum molle were used, accounting 26.6 and $19.5 \%$ of the wood of the grass covered house, respectively (Figure 7). E. camaldulensis and C. africana were used for house construction in all of the agro-ecologies because of availability and quality, respectively. The grass species used were different in different agro-ecologies but generally named as grass. C.africana, J. procera, $F$. sur and rarely $E$. camaldulensis lumber (sawn wood) were used for internal partitioning, making doors and windows of both types of houses. There was 14 different parts of a grass covered wooden house including roof covered by grass, central axis and surrounding wall (Figure 3 and Table 2). Corrugated iron sheet covered houses have six major parts including vertical wall, horizontal wall fastener, beam (roof) and pillars (big corner walls); internal partition, doors and windows.

\subsection{Shape, and size of wooden houses}

The shape of house was mainly determined by the availability of material for construction, economic status and the preferred aesthetic value of the house to the households. Most of the grass covered houses were circular and most of the corrugated ironsheet covered houses were rectangular (Table 3). However, there were very few corrugated ironsheet covered houses and grass covered houses with circular and rectangular shapes, respectively, which were not included in this study. The size of house was determined by the availability of wood and economic capacity of households. The size of grass covered wooden house was 59.0- $78.7 \mathrm{~m}^{2}$ while the corrugated iron sheet covered wooden houses was $78.1-110.3 \mathrm{~m}^{2}$, with conical and rectangular floor, respectively (Table 3 ). Greater size of house was observed in midland because of the availability of wood from Eucalyptus plantion forest (Figure 7). It was also observed that the size of corrugated ironsheet covered houses was greater than grass covered wooden houses (Table 3 ) because of the improvement in economic status of households.

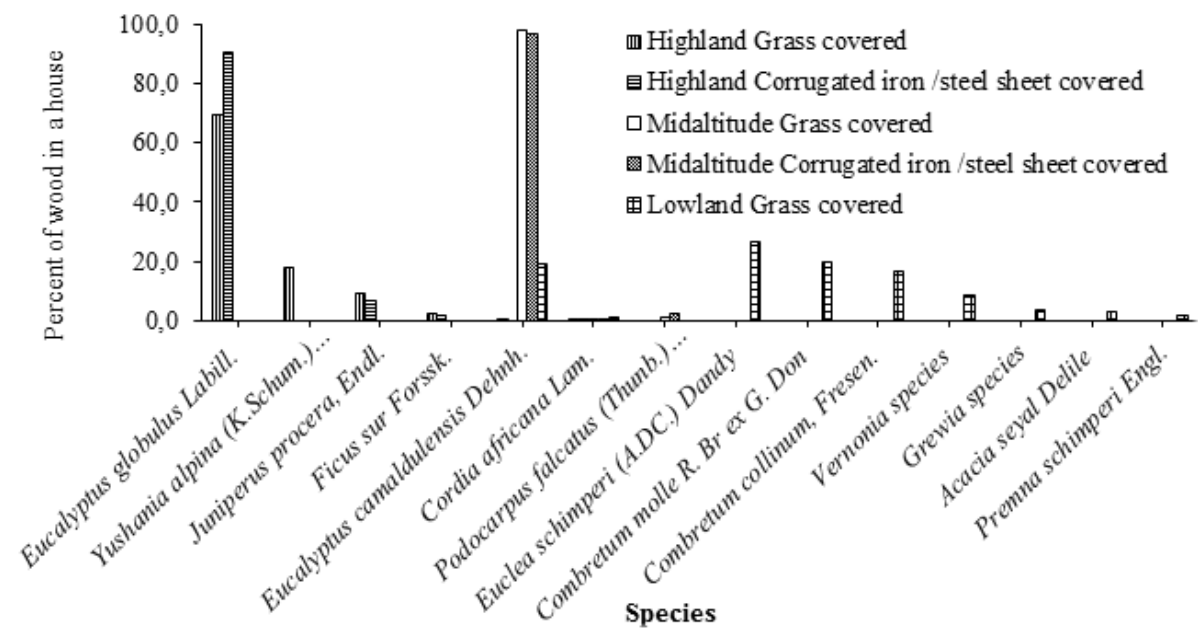

Figure 7: Major tree species used in construction of wooden houses in different agroecologies.

Table 3: Shape, and size of wooden houses of PAs

\begin{tabular}{|c|c|c|c|}
\hline Peasant association, agro-ecology & House cover of wooden houses & Shape of floor wall \&roof of house & Area $\left(m^{2}\right)($ mean + St.Er. $)$ \\
\hline Awed, highland & Grass & Circular, \& conical & $60.0 \pm 3.5$ \\
\hline Daemir, midland & Grass & $"$ & $78.7 \pm 5.2$ \\
\hline Ener Kola, lowland & Grass & $"$ & $59.0 \pm 8.9$ \\
\hline Awed, highland & Corrugated iron sheet & Rectangular triangular \&trapezoid & $78.1 \pm 7.8$ \\
\hline Daemir, midland & Corrugated iron sheet & $"$ & $110.3 \pm 10.3$ \\
\hline
\end{tabular}




\subsection{Carbon storage of scattered trees, wooden houses and grazing land}

As observed and responded by the households, the wood used for both grass covered and corrugated ironsheet covered houses was the same type of species that is available in the locality or in the nearby market. As can be seen from Table 4, the density and carbon content of wood, grass and soot used for grass and corrugated iron sheet covered houses at specified moisture content was different. The soot is the byproduct in biomass combustion accumulated in the internal roofs of both types of house covers. The size of wood or diameter at breast height (DBH) used was different for different parts of the house. That is the values in Table 4 are from samples taken from different houses but from the same plant species in a given altitudinal range or peasant association. In the woods of trees used for house construction, the highest carbon concentration of about $59.2 \%$ was found in matured stem wood lumber of C. africana and the lowest about $19.9 \%$ in young wood of E. camaldulensis (Table 4). Matured tree species like E. globulus grown for $60-80$ years have carbon content of $53.7 \%$ (Table 4). The overall mean carbon content of the wood used for house construction was $46.7 \%$. The densest wood was obtained at the stump height of Grewia species $(0.92 \mathrm{~g} \mathrm{~cm}$ $\left.{ }^{3}\right)$, while the lightest from young trees of $E$. camaldulensis $\left(0.33 \mathrm{~g} \mathrm{~cm}^{-3}\right)$ (Table 4). The overall mean density of wood used for construction was $0.682 \mathrm{~g} \mathrm{~cm}^{-3}$. The carbon content of grass was the highest in the highland about 50\% and the lowest in lowland about 48\% (Table 4). The carbon content of soot was the highest in highland grass covered wooden houses about $50.4 \%$ and the lowest in midland corrugated ironsheet covered houses about 32\% (Table 4).

The carbon storage time of wood used for grass covered wooden houses was estimated to be 16-100 years in highland, and 5-70 years in lowland PA but for corrugated iron sheet covered houses from 54.2-150 in highland PA and 34.3-124.1 in midland (Table 5). However, the service life of the whole houses was 20.8-107.1 years (Table 5). The service life was lower than the carbon storage time because all the wood used for construction did not have equal durability. The service life of houses could terminate when most of the wood decompose, but still some durable wood type will remain without decomposition and keep the carbon for longer period of time in the same or different places.

Table 4: Mean density, carbon and moisture content of woody species, and grass used and soot accumulated in grass and corrugated iron sheet covered wooden houses

\begin{tabular}{|c|c|c|c|c|c|c|c|c|c|c|c|c|c|c|c|c|c|c|c|c|}
\hline \multirow[t]{2}{*}{ Plant species } & \multicolumn{4}{|c|}{$\begin{array}{l}\text { Central support axis } \\
\text { "Miseso" }>40 \mathrm{~cm} \mathrm{DBH} \\
\text { overbark }\end{array}$} & \multicolumn{4}{|c|}{$\begin{array}{c}\text { Surrounding wall } \\
\text { (30-40 cm DBH overbark) } \\
\text { (above } \& \text { below ground) }\end{array}$} & \multicolumn{4}{|c|}{$\begin{array}{c}\text { Internal shelf maker for } \\
\text { livestock partition "Natere" } \\
\text { (15-30 cm DBH overbark) } \\
\text { (above \& below ground) }\end{array}$} & \multicolumn{4}{|c|}{$\begin{array}{c}\text { Small and big, or thin \& } \\
\text { thick solid poles }(5-15 \mathrm{~cm} \\
\text { DBH overbark) }\end{array}$} & \multicolumn{4}{|c|}{$\begin{array}{c}\text { Lumber } \\
\text { (for trees }>20 \mathrm{~cm} \text { DBH } \\
\text { overbark) }\end{array}$} \\
\hline & $\begin{array}{l}\text { Density } \\
\left(\mathrm{gcm}^{-3}\right)\end{array}$ & $\begin{array}{c}\mathrm{MC}_{1} \\
(\%)\end{array}$ & $\begin{array}{c}\text { C } \\
(\%)\end{array}$ & $\begin{array}{r}\mathrm{MC}_{2} \\
(\%)\end{array}$ & $\begin{array}{l}\text { Density } \\
\left(\mathrm{gcm}^{-3}\right)\end{array}$ & $\begin{array}{l}\mathrm{MC}_{1} \\
(\%)\end{array}$ & $\begin{array}{c}\text { C } \\
(\%)\end{array}$ & $\begin{array}{r}\mathrm{MC}_{2} \\
(\%)\end{array}$ & $\begin{array}{l}\text { Density } \\
\left(\mathrm{gcm}^{-3}\right)\end{array}$ & $\begin{array}{l}\mathrm{MC}_{1} \\
(\%)\end{array}$ & $\begin{array}{c}\text { C } \\
(\%)\end{array}$ & $\mathrm{MC}_{2} \%$ & $\begin{array}{l}\text { Density } \\
\left(\mathrm{gcm}^{-3}\right)\end{array}$ & $\begin{array}{l}\mathrm{MC}_{1} \\
(\%)\end{array}$ & $\begin{array}{l}\text { C } \\
(\%)\end{array}$ & $\begin{array}{r}\mathrm{MC}_{2} \\
(\%)\end{array}$ & $\begin{array}{l}\text { Density } \\
\mathrm{gcm}^{-3}\end{array}$ & $\begin{array}{l}\mathrm{MC}_{1} \\
(\%)\end{array}$ & $\begin{array}{c}\text { C } \\
(\%)\end{array}$ & $\begin{array}{r}\mathrm{MC}_{2} \\
(\%)\end{array}$ \\
\hline Eucalyptus camaldulensis Dehnh & 0.74 & 9.7 & 51.6 & 23.8 & 0.66 & 7.1 & 40.0 & 9.4 & 0.5 & 7.7 & 37.4 & 10.6 & 0.33 & 9.1 & 19.9 & 8.7 & & & & \\
\hline Eucalyptus globulus Labill. & & & & & 0.80 & 8.2 & 53.7 & 8.7 & 0.82 & 6.1 & 41.2 & 10.3 & 0.46 & 10.2 & & & & & & \\
\hline Grewia sp. & & & & & 0.92 & 11.8 & 44.0 & 8.0 & & & & & & & & & & & & \\
\hline Juniperus procera Hochst. Ex Endl. & 0.64 & 12.7 & 52.7 & 11.2 & 0.47 & 10.8 & 47.5 & 11.8 & & & & & & & & & & & & \\
\hline Cordia africana Lam. & & & & & & & & & & & & & & & & & 0.52 & 12.8 & 59.2 & 12.4 \\
\hline Podocarpus falcatus (Thunb.) RBr. ex Mirb. & & & & & & & & & & & & & & & & & 0.44 & 13.2 & 50.0 & 12.0 \\
\hline Vernonia sp. & & & & & & & & & & & & & 0.54 & 12.0 & 50.0 & 11.5 & & & & \\
\hline Premna schimperi Engl. & & & & & 0.79 & 12.3 & 50.3 & 9.3 & & & & & & & & & & & & \\
\hline Euclea schimperi (A.DC.)Dandy & & & & & & & & & 0.9 & 14.9 & 58.5 & 12.8 & 0.81 & 11.6 & 53.3 & 12.5 & & & & \\
\hline Acacia seyal Delile & & & & & 0.86 & 8.6 & 50.0 & 12.0 & & & & & & & & & & & & \\
\hline Faidherbia albida (syn. Acacia albida) Delile & & & & & 0.87 & 7.6 & 50.0 & 9.5 & & & & & & & & & & & & \\
\hline Combretum collinum Fres. & 0.88 & 10.8 & 50.3 & 15.3 & 0.78 & 14.5 & 47.7 & 11.1 & & & & & 0.73 & 14.3 & 45.4 & 12.8 & & & & \\
\hline C.molle RBr ex G. Don & & & & & & & & & & & & & 0.74 & 14.6 & 49.4 & 12.1 & & & & \\
\hline Ficus sur Forssk. & & & & & & & & & & & & & & & & & 0.47 & 13.7 & 49.9 & 11.6 \\
\hline Yushania alpina (K. Schum.) W.C.Lin & & & & & & & & & & & & & & & & & 0.55 & 11.4 & 48.0 & 9.4 \\
\hline D.angustifolia L.f. & & & & & & & & & & & & & & & & & 0.77 & 7.2 & 50.0 & 12.0 \\
\hline A.Schimperi (A.DC.) Schweinf. & & & & & & & & & & & & & & & & & 0.73 & 14.4 & 50.0 & 12.0 \\
\hline Grass in Ener Kola PA & & & 44.8 & 10.5 & & & & & & & & & & & & & & & & \\
\hline Grass in Daemir PA & & & 48.4 & 9.5 & & & & & & & & & & & & & & & & \\
\hline Grass in Awed PA & & & 50.0 & 9.8 & & & & & & & & & & & & & & & & \\
\hline Soot in Ener Kola grass covered house & & & 44.6 & 13.3 & & & & & & & & & & & & & & & & \\
\hline Soot in Daemir grass covered house & & & 48.0 & 14.1 & & & & & & & & & & & & & & & & \\
\hline Soot in Daemir iron/steel sheet covered house & & & 32.0 & 5.70 & & & & & & & & & & & & & & & & \\
\hline Soot in Awed grass covered house & & & 50.4 & 12.5 & & & & & & & & & & & & & & & & \\
\hline Soot in Awed iron/steel sheet covered house & & & 40.6 & 5.70 & & & & & & & & & & & & & & & & \\
\hline
\end{tabular}


Table 5: Mean and ranges of service and carbon storage age of rural wooden houses

\begin{tabular}{|c|c|c|c|}
\hline Peasant association & $\begin{array}{c}\text { House cover of wooden } \\
\text { houses }\end{array}$ & $\begin{array}{c}\text { Service age ranges of } \\
\text { wooden houses (years) }\end{array}$ & $\begin{array}{c}\text { Mean service age and } \\
\text { carbon storage of wooden } \\
\text { houses (years) }\end{array}$ \\
\hline Awed & Grass & $50-80$ & 67.4 \\
\hline Daemir & Grass & $44-100$ & 69.2 \\
\hline Ener Kola & Grass & $15-30$ & 20.8 \\
\hline Awed & Corrugated iron sheet & $90-120$ & $17.8-90$ \\
\hline Daemir & Corrugated iron sheet & $66-125$ & $5.2-70$ \\
\hline
\end{tabular}

In the soil, the carbon content was significantly higher $(p<0.05)$ at the top $0-5 \mathrm{~cm}$ depth than the others depths (Table 6). At $1 \mathrm{~m}$ depth the highest mean carbon concentration $\left(17.33 \mathrm{mg} \mathrm{C} \mathrm{g}^{-1}\right)$ was obtained in midland and the lowest (10 $\mathrm{mg} \mathrm{C} \mathrm{g}^{-1}$ ) in lowland (Table 6).

The above ground carbon storage of grass covered wooden house was 28.4 - $49.21 \mathrm{~kg} \mathrm{C} \mathrm{m}^{-2}$ when the house construction was completed (Table 7). The grazing land grass and soil carbon stock varied locally and it ranged in lowland to highland from $0.127-0.185 \mathrm{~kg} \mathrm{C} \mathrm{m}^{-2}$ and 24.473- $28.213 \mathrm{~kg} \mathrm{C} \mathrm{m}^{-2}$, respectively (Table 7).

Rural grass covered wooden houses were serving for 15-30 years in Ener Kola, lowland PA and 44-100 years in Daemir, midland PA with mean of 20.8- 69.2 years. The corrugated iron sheet covered wooden houses were serving for 66-125 years in Daemir PA and 90120 years in Awed PA, with mean of 99-107 years, depending on the durability of wood used (Table 5). The service age of wooden houses is determined by the type of wood, agro-ecology and the presence of decomposing agents. If the wood decomposes easily, converted to $\mathrm{CO}^{2}$ and other components of the wood, the service age will be less. It was observed that Juniperus species using cold climate highland houses have longer age than the others because of the species' resistance to decomposition. Since the wooden house comprise different species of wood, the carbon storage also depends on the species. The carbon storage was 5.2-100 years in the case of grass covered houses and 34.3-150 in the case of corrugated iron sheet covered houses (Table 5). The 16.8-100 years carbon storage but the 50-80 years service age in Awed, highland PA, forexample, can be attributed to the decomposition of some of the wood used in the house construction but the house may serve in the presence of some of the wood components. Some of the wood could serve additional years in the new construction even after the total collapse of the old house.

Table 7 showed that the total carbon stock of grass covered houses was greater than the other landuses studied. The carbon storage in corrugated iron sheet covered wooden house of highland and midland agro-ecology $\left(357.00 * 10-4-637.00 * 10-4 \mathrm{~kg} \mathrm{C} \mathrm{m}^{-2}\right)$ was less than the grass covered wooden house because of the presence of grass in the later (Table 7). There was no corrugated iron sheet

Table 6: Soil carbon storage of three peasant associations at different depths

\begin{tabular}{|c|c|c|c|}
\hline Depth of soil from the surface $(\mathrm{cm})$ & $\begin{array}{c}\text { Highland PA, Awed } \mathrm{mg} \mathrm{C}^{-1} \text { of soil } \\
\text { (Mean } \pm \text { Std. Er. of Mean) }\end{array}$ & $\begin{array}{c}\text { Midland PA, Daemir mg C } \mathrm{g}^{-1} \text { of soil } \\
\quad(\text { Mean } \pm \text { Std. Er. of Mean) }\end{array}$ & $\begin{array}{c}\text { Lowland PA, Ener Kola mg C g-1 of } \\
\text { soil (Mean } \pm \text { Std. Er. of Mean) }\end{array}$ \\
\hline $0-5$ & $47.983 \pm 5.517^{c}$ & $48.767 \pm 4.691^{c}$ & $46.229 \pm 6.729^{b}$ \\
\hline $5-15$ & $34.850 \pm 5.238^{\mathrm{bc}}$ & $36.633 \pm 3.412^{b}$ & $27.843 \pm 2.480^{\mathrm{a}}$ \\
\hline $15-30$ & $30.483 \pm 4.870^{\mathrm{b}}$ & $26.683 \pm 3.809^{\mathrm{ab}}$ & $26.629 \pm 3.782^{\mathrm{a}}$ \\
\hline $30-50$ & $24.167 \pm 1.638^{\mathrm{ab}}$ & $27.41 \pm 3.176^{\mathrm{ab}}$ & $20.071 \pm 2.805^{a}$ \\
\hline $50-100$ & $13.000 \pm 1.970^{\mathrm{a}}$ & $17.333 \pm 2.667^{\mathrm{a}}$ & $10.233 \pm 0.233^{\mathrm{a}}$ \\
\hline
\end{tabular}

Note: $\mathrm{a}, \mathrm{b}$ and $\mathrm{c}$ are significantly different at $\mathrm{p}<0.05$; $\mathrm{mg}$ is milligram; $\mathrm{mg} \mathrm{C}^{-1}$ is milligram carbon per gram soil. 
Table 7: Carbon storage of dominant land uses (houses, grazing land and scattered trees) around rural wooden houses

\begin{tabular}{|c|c|c|c|c|c|c|c|c|c|c|c|c|}
\hline \multirow[t]{3}{*}{ PA } & \multicolumn{6}{|c|}{ Wooden houses carbon } & \multirow{2}{*}{\multicolumn{2}{|c|}{$\begin{array}{c}\text { Grazing land } \\
\text { carbon }\left(\mathrm{kg} \mathrm{C} \mathrm{m}^{-2}\right)\end{array}$}} & \multirow{2}{*}{\multicolumn{2}{|c|}{$\begin{array}{l}\text { Scattered trees } \\
\text { carbon }\left(\mathrm{kg} \mathrm{C} \mathrm{m}^{-2}\right)\end{array}$}} & \multirow[t]{3}{*}{$\begin{array}{c}\text { Precipitation } \\
(\mathrm{mm})\end{array}$} & \multirow[t]{3}{*}{$\begin{array}{c}\text { Temperature } \\
\left({ }^{\circ} \mathrm{C}\right)\end{array}$} \\
\hline & \multicolumn{3}{|c|}{$\begin{array}{l}\text { Grass covered wooden houses } \\
\text { carbon }\left(\mathrm{kg} \mathrm{C} \mathrm{m}^{-2}\right)\end{array}$} & \multicolumn{3}{|c|}{$\begin{array}{l}\text { Corrugated iron sheet } \\
\text { covered wooden houses } \\
\text { carbon }\left(\mathrm{kg} \mathrm{C} \mathrm{m}^{-2}\right)\end{array}$} & & & & & & \\
\hline & $\begin{array}{l}\text { Above } \\
\text { ground }\end{array}$ & $\begin{array}{l}\text { Below } \\
\text { ground }\end{array}$ & $\begin{array}{c}\text { Annual } \\
\text { soot }\end{array}$ & $\begin{array}{l}\text { Above } \\
\text { ground }\end{array}$ & $\begin{array}{l}\text { Below } \\
\text { ground }\end{array}$ & $\begin{array}{c}\text { Annual } \\
\text { soot }\end{array}$ & Grass & Soil & $\begin{array}{l}\text { Above } \\
\text { ground }\end{array}$ & $\begin{array}{l}\text { Below } \\
\text { ground }\end{array}$ & & \\
\hline Awed & 49.2607 & 0.0004 & 0.0007 & 0.0326 & 0.0031 & 0.0069 & 0.1456 & 24.7249 & 24.5037 & 4.9007 & 900 & 27.5 \\
\hline Daemir & 46.0990 & 0.0009 & 0.0013 & 0.0585 & 0.0052 & 0.0077 & 0.1847 & 28.2131 & 15.3342 & 3.0668 & 1150 & 18.5 \\
\hline Ener Kola & 28.3527 & 0.0006 & 0.0004 & na & na & na & 0.1266 & 24.4731 & 2.2333 & 0.4467 & 1400 & 13.5 \\
\hline
\end{tabular}

na $=$ not available

covered wooden houses in lowland, Ener Kola PA. The above ground carbon stock of the grass covered wooden house was also greater than the other landuses studied. However, the greatest below ground carbon storage was observed in grazing land soil followed by the scattered trees landuse (Table 7).

The grazing land use grass and soil total carbon stock was 50.5$86.8 \%$ and the remnant scattered trees carbon was $9.5-59.7 \%$ of the total carbon stock of the respective PA grass covered wooden houses (Table 7) indicating the absence of forests especially in the lowland PA. Moreover, the soil is the common below ground carbon stock to all landuses, and the total carbon stock of a landuse is mostly affected by the aboveground carbon stock.

Geo-climatic variables including altitude, precipitation and temperature of the study area were significantly correlated with above and below ground carbon storage of the studied land uses $(p<0.07 ; r$
$= \pm 0.999$ ) (Table 8). Generally, wood carbon content increased as the density of wood of a species increased and both positively correlated significantly $(p<0.07 ; r=0.47$ ) (Table 8$)$.

\section{Soot organic carbon accumulation of wooden houses}

The soot carbon was accumulated in the internal part of the roof of wooden houses that use solid biomass fuel for energy. The soot was stored temporarily and could be removed by clearing. In the studied lowland to highland PAs, a total of $3.93-12.68 \mathrm{~g} \mathrm{C} \mathrm{m}^{-2} \mathrm{yr}^{-1}$ soot carbon was accumulated under the roof of wooden houses (Table 7) because of open stove fire used for cooking fuel. The soot carbon content of grass covered wooden house was higher than the corrugated iron sheet covered wooden houses in Daemir PA, which could be attributed to the confounding effect of grass in the soot (Table 7).

Table 8: Correlations of carbon storages with wood density and geo-climatic variables $(n=3)$

\begin{tabular}{|c|c|c|c|c|}
\hline & & Altitude & Precipitation & Temp. $\left({ }^{\circ} \mathrm{C}\right)$ \\
\hline Wood carbon content (\%) & $0.470^{*}$ & & & \\
\hline Soil carbon $\left(\mathrm{k} \mathrm{C} \mathrm{m}^{-2}\right)$ & & -0.189 & -0.196 & 0.157 \\
\hline Above ground living woody plants carbon $\left(\mathrm{kg} \mathrm{C} \mathrm{m}^{-2}\right)$ & & $0.996^{*}$ & $0.995^{\star}$ & $-0.998^{*}$ \\
\hline Below ground living woody plant carbon $\left(\mathrm{kg} \mathrm{C} \mathrm{m}^{-2}\right)$ & & $0.996^{*}$ & $0.995^{*}$ & $-0.998^{*}$ \\
\hline Above ground carbon of grass covered wooden house $\left(\mathrm{kg} \mathrm{C} \mathrm{m}^{-2}\right)$ & & 0.93 & 0.928 & -0.942 \\
\hline Below ground carbon of grass covered wooden house $(\mathrm{kg}$ & & -0.435 & -0.442 & 0.405 \\
\hline
\end{tabular}




\section{Discussion}

Rural wooden houses as settlemets were surrounded by different landuses, mainly grazing land and scattered trees, which serve as carbon storage features. Wooden houses were storing biomass carbon in wood and grass, grazing lands were storing carbon in grass grass and soil, and scattered trees landuse in above ground stems, branches and leaves and belowground roots. Although soil carbon is the below ground carbon stock in all landuses considered, the results dealt only on the houses and trees with grazing land soil. During the study period, the natural forest was scanty in all the study sites due to reckless cutting and clearing for agricultural land, new settlements house construction and charcoal making. In lowland, there was remnant natural vegetation of Acacia and Combretum species. In midland and highland, there was Eucalyptus camaldulensis and $E$. globulus plantation, respectively. Species like C. africana, Ficus sur, $J$. procera, and $P$. falcatus were needed to make lumber for door and window of houses. These species were obtained locally in lowland and home gardens of midland but purchased from markets in the highland. Then preference of tree species used for house construction was determined by the availability of the species within the nearby forest or market as stated in Sheikh et al., (2009).

The availability of different tree/shrub species of wood and the economic status of households determined the construction of different sized houses. The PA officials informed that, small houses were built by poor households and bigger houses by the riches. The decrease in the availability of grass due to land use change contributed to the construction of corrugated ironsheet covered houses. The shape of most of the grass covered houses was commonly with circular floor and conical roof as stated in other studies (Alemayehu, 2011) while the corrugate iron sheet covered houses were commonly with rectangular floor and triangular/ trapezoidal roof (Table 3).

The type of wood used for construction of different parts of grass covered and corrugated iron sheet covered wooden houses was also different depending on the required strength of wood. For example, straight, long, strong and durable wood was commonly used for the central support (Axis) and surrounding wall as stated in other studies (Sarmiento et al., 2010) and the least strong wood was used for the roof, where there is no contact with soil (Table 2 ). The density and carbon content of wood of tree species used for house construction varied with diameter and stem position (Table 4) (Yeboah et al., 2013). Matured trees resulted in higher wood density and carbon stock than younger ones depending on moisture content, growth habit and health condition as confirmed in other studies (Dale, 2014; Kinyanjui, 2014). However, Martin, Doraisami, and Thomas (2018) showed that the wood carbon decrease as wood density increases. The overall mean carbon concentration of wood used for house construction in the present study, about $46.7 \%$ was in line with other studies (Chen et al., 2015; Djomo, Knohl, \& Gravenhorst, 2011; Martin, Doraisami, \& Thomas, 2018; Navaro et al., 2013; Yeboah et al., 2013), however, the minimum about $19.9 \%$ was lower than the $28 \%$ obtained in other study (Martin, Doraisami, \& Thomas, 2018) which could be attributed to the young stems of low lignification. Therefore, further study is important on diameter of trees, wood density and their carbon concentration at different agrecologies and site condition.

The carbon stock of wooden houses was also determined by the type of woody species used for house construction and size of houses. In wooden houses, higher carbon storage was obtained in highland than lowland (Table 3) because of the temperature condition by which the highland is cold that require stronger and tightly constructed house with more wood, but the lowland is usually warm and dominated by temporarily constructed houses that require less durable biomass. However, a study conducted in Kwazulu, in South Africa, reported that the volume of wood of a house was greater in lowland than in highland situations (Liengme, 1983), which could indicate the use of voluminous woody branches and leaves in lowland. The carbon storage time of wooden house could be longer than a century if decay is hindered and protected from damages (Table 3). The above ground carbon storage in grass covered wooden houses in highland PA, and midland PA in the present study (46.1-49.26 $\left.\mathrm{kg} \mathrm{C} \mathrm{m}^{-2}\right)$ was higher than the study made by Churkina et al., (2010) (23-42 kg C $\mathrm{m}^{-2}$ ) in urban settlements and elsewhere in the world by Laganière et al., (2010), which could be attributed to the use of dense wood and the use of biomass for construction of the entire house. The carbon storage of wooden house could be more permanent sink than living trees in societies that use biomass energy by continuous cutting of trees deliberately as observed in the studied rural areas.

Carbon storage of different land uses varied with the type of geoclimatic (agroecology, or altitude) conditions. The relatively lower carbon stock obtained in grazing land soil and remnant scattered trees when compared to grass covered wooden houses opposes the previous results of Yin et al., (2012) and Gupta and Sharma (2013) because of dense wood used for rural house construction and high rate of deforestation. Although the carbon storage time for wooden house can be increased by different techniques that reduce wood decay to about a century, the carbon storage of soil is for millennia (Rumpel \& Kögel-Knabner, 2010). In grazing land use, continuous grazing and natural annual lifecycle removed the grass in which case the above ground carbon stock was negligible and could not be taken as a perennial nor permanent carbon stock. That is the above ground grasses with short annual life added carbon to soil. The soil carbon in highland and lowland was lower than midland (Table 6), this might be due to rugged topographic nature of the highland that facilitate runoff and the higher temperature of the lowland that facilitate oxidation, which is in line with Demessie, Singh, and Lal (2016). The total carbon stock of landuses surrounding rural wooden houses that include grass covered wooden house decreased as the altitude decreased from highland $\left(49.26 \mathrm{~kg} \mathrm{C} \mathrm{m}^{-2}\right)$ to lowland (28.35 $\left.\mathrm{kg} \mathrm{C} \mathrm{m}{ }^{-2}\right)$, and remnant woody plants from highland $\left(29.4 \mathrm{~kg} \mathrm{C} \mathrm{m}^{-2}\right)$ to lowland $\left(2.68 \mathrm{~kg} \mathrm{C} \mathrm{m}^{-2}\right.$ ) of the present study area as studied in Mwakisunga and Majule (2012) but opposes the total carbon stock studied by Simegn and Soromessa, (2015). The decrease in carbon storage with increased depth of soil (Table 6) was comparable with other studies carried out elsewhere (Tesfaye et al., 2016). At the end of $1 \mathrm{~m}$ depth the highest carbon stock in midland as compared to the other agro-ecologies (Table 6) was attributed to the flat topography and the intermediate temperature level as stated in $\mathrm{Xu}$, Dong, and Yang, (2017). 
Low carbon stock of standing trees was obtained in lowland PA (Table 3 ) because of deforestation. Although, eucalyptus plantation in tropical conditions are highly productive, the frequent harvesting at faster rate of 5-10 years in midland of the present study hindered the maturity of stands of the standing live Eucalyptus camaldulensis, which reduced the carbon stock (Table 7) than the highland. The above ground carbon storage (Hairiah et al., 2010; IPCC, 2006) of E. globulus plantation in the highland of this study was higher than other studies (Berta, Soromessa, \& Belliethathan, 2015), which can be attributed to long time conservation of live trees without cutting. Generally, the accumulation of higher carbon in grass covered wooden houses than either soil or remnant scatted trees landuse indicated the decline of forest cover (Table 7). There was strong correlation between the land uses and the carbon storage $(p<0.05 ; r= \pm 0.999)$ (Table 8), indicating that carbon storage of an area is affected by the type of land use and agroecology as stated in other studies (England et al., 2016).

Soot carbon stock, as incomplete combustion of fuel could be as high as $1.268 * 10^{-2} \mathrm{~kg} \mathrm{~m}^{-2}$ (Table 7 ) in wooden houses, but it might not be permanent carbon stock if the roofs of wooden houses are kept clean continuously. The rural households responded that more soot was an indication of poverty. Soot is also the main indoor pollutant (IPCC, 2014). During the study period all the households encountered, informed that some member of the households face eye and breathing problems sometimes in life due to indoor pollution by soot and smoke. The soot accumulated contains sulfur and its health effect was very common (Fekadu, Bekele, \& Feleke, 2017). Since wooden houses store carbon in constructed wood and soot more than soil and standing living trees (Table 7), it is important to consider these wooden houses carbon storage in climate change mitigation. Although rural wooden houses store carbon, the residents suffer from soot carbon indoor pollution. Therefore, wooden houses should be supported for the carbon stored by climate change financial mechanisms to solve the problem of indoor pollution.

The construction of wooden houses that use sustainably harvested biomass has no wastage of wood per se due to cutting of trees because rural areas usually use the residual biomass for energy (Sedjo, 2011). Other studies stated that houses built using wood and grasses are more cost and time efficient than those made of concrete and iron (Hurmekoski, 2017). Constructing houses using wood and grass is one way of offsetting emission as stated in other studies (Hurmekoski, 2017; Kayo, \& Noda, 2018; Reid et al., 2004). Houses made of hollow concrete block can serve for over a century as close as to the wooden houses of about a century (personal communication). It was agrued that, using a combination of wood and concrete for house construction is important to offset emission in long staying houses by reducing decay, indoor pollution and deforestation.

\section{Conclusions and Recommendations}

The availability of wood from different tree species and economic condition of households determined the type and size of wooden house construction. Carbon content variation of different plant species, and different agroecologies resulted in different amount of carbon storage of land use per unit area. From the tree species used for house construction $C$. africana showed the highest carbon concentration (59. 2\%) and Grewia species showed the highest wood density $\left(0.92 \mathrm{~g} \mathrm{~cm}^{-3}\right)$. The carbon storage time of wood used for house construction in the present study was 5-150 years depending on the type of house cover, agro-ecology, site condition and woody species. Rural grass covered wooden houses at a time stored 28.4$49.21 \mathrm{~kg} \mathrm{C} \mathrm{m}^{-2}$.

The total carbon stock of grazing land and its soil was $50.5-86.8 \%$ and the remnant scattered trees carbon was $9.5-59.7 \%$ of the total carbon stock of the respective PA grass covered wooden houses (Table 7). Therefore, carbon stock is shifting from forests to built structures, called rural wooden houses in human dominated landscapes, this may have an implication to distrupt the carbon stock, photosynthesis, and reduce oxygen supply. Wood harvesting for wooden house construction was one way of storing carbon outside the forest and wood residues left during house construction were used as firewood as the main sources of cooking energy that made no wastage of wood.

Carbon storages of grass in grazing land and soot in wooden houses were temporary because they can be removed by continuous grazing and cleaning, respectively. Although wooden houses store carbon, the residents were suffering from soot indoor pollution and deforestation, hence means of reducing indoor pollution, improving the house ventilation, introducing clean cooking technologies, increasing the life span of houses and afforestation measures should be practiced. The carbon stock of soot in midland was higher than the highland and lowland, which could be attributed to continuous indoor cooking in the presence of ample firewood. Avoiding wood decay through appropriate storage of wood in the cases of constructed wooden houses and the storage of leafy and bark residues that to be used as biomass energy should be trained to the rural people in order to reduce deforestation. In the future, it is important to identify methods of increasing the life span of wooden houses such as combining wood and iron / steel materials and cementing the basement parts in contact with soil to reduce decay. The field observation revealed that the indigenous tree species used for house construction were few inaddtion to the overall reduction of forest, and therefore, efforts should be strengthened to increase forest cover.

\section{Acknowledgements}

The research was financially supported by Hawassa University, Wondo Genet College of Forestry and Natural Resources, Central Ethiopia Environment and Forestry Research Center, and Association of African Universities Small Grant for Post Graduate Theses and Dissertations. We would like to thank Mehari Alebachew and anonymous reviewers for their valuable comments.

\section{References}

Alemayehu, E. Y. (2011). Rural housing skill transfer and the milestones for scaling-up: 
The case of sustainable rural dwelling units (SRDU) in Ethiopia. African Technology Development Forum Journal, 8(3-4), 24-28.

Baccini, A., Goetz, S. J., Walker, W. S., Laporte, N. T., Sun, M., Sulla-Menashe, D., ... Houghton, R. A. (2012). Estimated carbon dioxide emissions from tropical deforestation improved by carbon-density maps. Nature Climate Change, 2(3), 182-185. doi: https://doi. org/10.1038/nclimate1354

Bekele-Tesema, A. (2007). Useful trees and shrubs of Ethiopia: Identification, propagation and management for 17 agroclimatic zones. Nairobi Kenya: RELMA in ICRAF Project. World Agroforestry Centre - Eastern Africa Region Programme. Retrieved from: http://www.worldagroforestry.org/downloads/Publications/PDFS/B15056.pdf

Berta, A., Soromessa, T., \& Belliethathan, S. (2015). Carbon sock of Gambella National Park. Implication for climate change mitigation. Advances in Life Science and Technology, 35, 41-55. Retrieved from: http://ow.ly/xAXt30pgpFf

Bryman, A. (2012). Social research methods, 4th ed. New York: Oxford University Press Inc.

Casarim, F., \& Grais, A. (2013). Forest Carbon Sampling. LEAF Technical Training on Forest Carbon Assessment. Retrived from: https://www.leafasia.org/sites/default/files/ resources/2-LEAF_Biomass_C_sampling_intro.pdf

Central Statistical Agency and World Bank. (2013). Ethiopia rural socioeconomic survey (ERSS). Addis Ababa, Ethiopia. Retrieved from: http://ow.ly/ROYf30pfO0q

Chang, R., Fu, B., Liu, G., \& Liu, S. (2011). Soil Carbon Sequestration Potential for "Grain for Green" Project in Loess Plateau, China. Environmental Management, 48(6), 1158-1172. doi: https://doi.org/10.1007/s00267-011-9682-8

Chen, Y., Liu, Z., Rao, X., Wang, X., Liang, C., Lin, Y., Zhou, L., Cai, X., \& Fu, S. (2015). Carbon storage and allocation pattern in plant biomass among different forest plantation stands in Guangdong, China. Forests, 6(12), 794-808. doi: https://doi.org/10.3390/ f6030794

Churkina, G., Brown, D. G., \& Keoleian, G. (2010). Carbon stored in human settlements: the conterminous United States: Carbon in human settlements," Global Change Biology, 16(1), 135-143. doi: https://doi.org/10.1111/j.1365-2486.2009.02002.x

Cruz de León, G., \& Uranga-Valencia, L. P. (2013). Theoretical evaluation of Huber and Smalian methods applied to tree stem classical geometries. Bosque (Valdivia), 34(3), 311-317. doi: https://doi.org/10.4067/s0717-92002013000300007

Dale, M. J. (2014). Evaluation of methods for quantifying carbon storage of urban trees in New Zealand. Retrieved from: http://ow.ly/sV6g30pgpbB

Demessie, A., Singh, B. R., \& Lal, R. (2016). Soil Carbon Sequestration: Ethiopia. Encyclopedia of Soil Science, Third Edition, 2066-2072. doi: https://doi.org/10.1081/eess3-120053587

Deng, L., Wang, K.-B., Chen, M.-L., Shangguan, Z.-P., \& Sweeney, S. (2013). Soil organic carbon storage capacity positively related to forest succession on the Loess Plateau, China. CATENA, 110, 1-7. doi: https://doi.org/10.1016/j.catena.2013.06.016

Djomo, A. N., Knohl, A., \& Gravenhorst, G. (2011). Estimations of total ecosystem carbon pools distribution and carbon biomass current annual increment of a moist tropical forest. Forest Ecology and Management, 261(8), 1448-1459. doi: https://doi. org/10.1016/j.foreco.2011.01.031

Don, A., Schumacher, J., \& Freibauer, A. (2010). Impact of tropical land-use change on soil organic carbon stocks - a meta-analysis. Global Change Biology, 17(4), 1658-1670. doi: https://doi.org/10.1111/j.1365-2486.2010.02336.x

England, J. R., Paul, K. I., Cunningham, S. C., Madhavan, D. B., Baker, T. G., Read, Z., Wilson, B. R., Cavagnaro, T. R., Lewis, T., Perring, M. P., Herrmann, T. H., \& Polglase, P. J. (2016). Previous land use and climate influence differences in soil organic carbon following reforestation of agricultural land with mixed-species plantings. Agriculture, Ecosystems \& Environment, 227, 61-72. doi: https://doi.org/10.1016/j.agee.2016.04.026

Fekadu, M., Bekele, T., \& Feleke, S. (2017). Impact of Energy Consumption on Indoor Pollution in Rural Wooden Houses of Southern Ethiopia in times of Climate Change. Global Journal of Current Research, 4(3), 14-24.
Govett, R., Mace, T., \& Bowe, S. (2010). A practical guide for the determination of moisture content of woody biomass. Retrieved from: https://dnr.wi.gov/topic/ForestBusinesses/ documents/BiomassMoistureContent.pdf

Government of Alberta. (2012). Best practices field procedures for height and diameter measurement. Retrieved from: http://ow.ly/tj3r30pgmZN

Gupta, M., \& Sharma, S. D. (2013). Sequestered Organic Carbon Status in the Soils under Grassland in Uttarakhand State, India. Applied Ecology and Environmental Sciences, 1(1), 7-9. doi: https://doi.org/10.12691/aees-1-1-2

Hairiah, K., Dewi, S., Agus, F., Velarde, S., Ekadinata, A., Rahayu, S., \& van Noordwijk, M. (2010). Measuring carbon stocks across land use systems: A Manual. Bogor, Indonesia. World Agroforestry Centre (ICRAF), SEA Regional Office. Retrieved from: http://ow.ly/ vHTA30pgpCp

Hurmekoski, E. (2017). How can wood construction reduce environmental degradation?. European Forest Institute. Retrieved from: http://ow.ly/vmfE30pgpUp

Ilyas, S. (2013). Allometric equation and carbon sequestration of Acacia mangium Willd. in coal mining reclamation areas. Civil and Environmental Research, 3(1), 8-16.

IPCC. (2006). 2006 IPCC Guidelines for National Greenhouse Gas Inventories. Eggleston H.S., Buendia L., Miwa K., Ngara T. and Tanabe K. (eds). Published: IGES, Japan. Retrieved from: https://www.ipcc-nggip.iges.or.jp/public/2006gl/vol4.html

IPCC. (2007). Climate Change 2007: The Physical Science Basis. Contribution of Working Group I to the Fourth Assessment Report of the Intergovernmental Panel on Climate Change. Solomon, S., D. Qin, M. Manning, Z. Chen, M. Marquis, K.B. Averyt, M. Tignor and H.L. Miller (Eds.). Cambridge University Press, Cambridge, United Kingdom and New York, NY, USA, 996 pp.

IPCC. (2014). Climate Change 2014: Mitigation of Climate Change. Contribution of Working Group III to the Fifth Assessment Report of the Intergovernmental Panel on Climate Change [Edenhofer, O., R. Pichs-Madruga, Y. Sokona, E. Farahani, S. Kadner, K. Seyboth, A. Adler, I. Baum, S. Brunner, P. Eickemeier, B. Kriemann, J. Savolainen, S. Schlömer, C. von Stechow, T. Zwickel and J.C. Minx (eds.)]. Cambridge University Press, Cambridge, United Kingdom and New York, NY, USA. Retrieved from: https://www. ipcc.ch/site/assets/uploads/2018/02/ipcc_wg3_ar5_frontmatter.pdf

Iticha, B. (2017). Ecosystem carbon storage and partitioning in Chato Afromontane forest: Its climate change mitigation and economic potential. International Journal of Environment, Agriculture and Biotechnology, 2(4), 1785-1794. doi: https://doi. org/10.22161/ijeab/2.4.41

Kankaria, A., Nongkynrih, B., \& Gupta, S., (2014). Indoor air pollution in India: Implications on health and its control. Indian Journal of Community Medicine, 39(4), 203. doi: https://doi.org/10.4103/0970-0218.143019

Kayo, C., \& Noda, R. (2018). Climate Change Mitigation Potential of Wood Use in Civil Engineering in Japan Based on Life-Cycle Assessment. Sustainability, 10(2), 561. doi: https://doi.org/10.3390/su10020561

Kinyanjui, M. J., Shisanya, C. A., Nyabuti, O. K., Waqo, W. P., \& Ojwala, M. A. (2014). Assessing Tree Species Dominance along an Agro Ecological Gradient in the Mau Forest Complex, Kenya. Open Journal of Ecology, 04(11), 662-670. doi: https://doi. org/10.4236/oje.2014.411056

Krajnc, N. (2015). Wood Fuels Handbook. FAO, Pristina. Retrieved from:

https://www.scribd.com/document/347445234/Wood-Fuels-Handbook-2015

Laganière, J., Angers, D. A., \& Paré, D. (2010). Carbon accumulation in agricultural soils after afforestation: a meta-analysis. Global Change Biology, 16(1), 439-453.

Lange, M., Eisenhauer, N., Sierra, C. A., Bessler, H., Engels, C., Griffiths, R. I., ... Gleixner, G. (2015). Plant diversity increases soil microbial activity and soil carbon storage. Nature Communications, 6(1). doi: https://doi.org/10.1038/ncomms7707

Li, D., Niu, S., \& Luo, Y. (2012). Global patterns of the dynamics of soil carbon and nitrogen stocks following afforestation: a meta-analysis. New Phytologist, 195(1), 172-181. doi: https://doi.org/10.1111/j.1469-8137.2012.04150.x

Liengme, C. A. (1983). A study of wood use for fuel and building in an area of Gazankulu. 
Bothalia, 14(2). doi: https://doi.org/10.4102/abc.v14i2.1169

Makhuvha, M., Arellano, R. M., \& Harney, D. M. W. (2014). Determination of bulk density, methods and impacts, with a case study from Los Bronces Mine, Chile. Applied Earth Science, 123(3), 196-205. doi: https://doi.org/10.1179/1743275814y.0000000058

Martin, A. R., Doraisami, M., \& Thomas, S. C. (2018). Global patterns in wood carbon concentration across the world's trees and forests. Nature Geoscience, 11(12), 915920. doi: https://doi.org/10.1038/s41561-018-0246-x

Moges, Y., Eshetu, Z., \& Nune, S. (2010). Ethiopian forest resources: current status and future management options in view of access to carbon finances. Literature review. Retrieved from: http://ow.ly/iAmZ30pgn0O

Mwakisunga, B., \& Majule, A. E. (2012). The influence of altitude and management on carbon stock quantities in rungwe forest, southern highland of Tanzania. Open Journal of Ecology, 02(04), 214-221. doi: https://doi.org/10.4236/oje.2012.24025

Navaro, M., Moya, R., Chazdon, R., Ortiz, E., \& Vilchez, B. (2013). Successional variation in carbon content and wood specific gravity of four tropical tree species. Bosque (Valdivia), 34(1), 9-10. doi: https://doi.org/10.4067/s0717-92002013000100005

Negussie, A. D. (2004). Farm forestry decision-making strategies of the Guraghe households, Southern-Central Highlands of Ethiopia. (Dissertation, Technischen Universität Dresden). Retrieved from: http://ow.ly/kQac30plEm7

Pan, Y., Birdsey, R.A., Fang, J., Houghton, R., Kauppi, P.E., Kurz, W.A., Phillips, O.L., Shvidenko, A., Lewis, S.L., Canadell, J.G., Ciais, P. R, Jackson, .B., Pacala, S.W., McGuire, A.D., Piao, S., Rautiainen, A., Sitch, S., \& Hayes, D.A. (2011). A large and persistent carbon sink in the world's forests. Science, 333(6045), 988-993. doi: https://doi.org/10.1126/ science. 1201609

Potter, B., \& Woodrom, I. (2017). Accounting for carbon storage in trees. The Royal Society of Victoria. Retrieved from: http://ow.ly/xQRT30pIEIK

Reid, H., Huq, S., Inkinen, A., MacGregor, J., Macqueen, D., Mayers, J., Murray, L., \& Tipper, R. (2004). Using wood products to mitigate climate change: A review of evidence and key issues for sustainable development. International Institute of Environment and Development. Retrieved from: http://ow.ly/Orei30pgpWw

Rumpel, C., \& Kögel-Knabner, I. (2010). Deep soil organic matter-a key but poorly understood component of terrestrial C cycle. Plant and Soil, 338(1-2), 143-158. doi: https://doi.org/10.1007/s11104-010-0391-5

Sanderman, J., Farquharson, R., \& Baldock, J. (2010). Soil carbon sequestration potential: A review for Australian agriculture. A report prepared for Department of Climate Change and Energy Efficiency, Australian Government.

Sarmiento, C., Patino, S., Paine, C. E. T., Beauchene, J., Thibaut, A., \& Baraloto, C. (2010). Within-individual variation of trunk and branch xylem density in tropical trees. American Journal of Botany, 98(1), 140-149. doi: https://doi.org/10.3732/ajb.1000034

Sedjo, R. A. (2011). Carbon neutrality and bioenergy: A zero-sum game?. Resources for the future, Dicussion paper, 11-15. Retrieved from: http://ow.ly/GtB030plEix

Shankar, R., Naresh, D., Joseph, B., Suneetha Devi, K.B., \& Aarifkhan, M.A. (2014). Dynamics of carbon storage and sequestration in major forest tree species of Andhrapradesh. Indian Journal of Applied Research, 4(11). Retrieved from: http://ow.ly/pwDb30plEjg

Sheikh, A. Q., \& Pandit, A. K. (2014). Terrestrial Carbon Sequestration as a Climate Change Mitigation Activity. Journal of Pollution Effects \& Control, 02(01). doi: https://doi. org/10.4172/2375-4397.1000110

Sheikh, M. A., Kumar, M., \& Bussmann, R. W. (2009). Altitudinal variation in soil organic carbon stock in coniferous subtropical and broadleaf temperate forests in Garhwal Himalaya. Carbon Balance and Management, 4(1). doi: https://doi.org/10.1186/17500680-4-6

Shiferaw, A., Hurni, H., \& Zeleke, G. (2013). A Review on Soil Carbon Sequestration in Ethiopia to Mitigate Land Degradation and Climate Change. Journal of Environment and Earth Science, 3(12), 187-200.

Sileshi, G. W. (2014). A critical review of forest biomass estimation models, common mistakes and corrective measures. Forest Ecology and Management, 329, 237-254. doi: https://doi.org/10.1016/j.foreco.2014.06.026

Simegn, T. Y. \& Soromessa, T. (2015). Carbon Stock Variations Along Altitudinal and Slope Gradient in the Forest Belt of Simen Mountains National Park, Ethiopia. American Journal of Environmental Protection, 4(4), 199. doi: https://doi.org/10.11648/j. ajep.20150404.15

Svob, S., Arroyo-Mora, J. P., \& Kalacska, M. (2014). A wood density and aboveground biomass variability assessment using pre-felling inventory data in Costa Rica. Carbon Balance and Management, 9(1). doi: https://doi.org/10.1186/s13021-014-0009-y

Tesfaye, M. A., Bravo, F., Ruiz-Peinado, R., Pando, V., \& Bravo-Oviedo, A. (2016). Impact of changes in land use, species and elevation on soil organic carbon and total nitrogen in Ethiopian Central Highlands. Geoderma, 261, 70-79. doi: https://doi.org/10.1016/j. geoderma.2015.06.022

UN DESA. (2017). World Population Prospects. Retrieved from: https://population.un.org/ wpp/

UNFCCC. (2001, Oct 29-Nov 9). Land Use, Land-Use Change and Forestry (LULUCF). Conference of the Parties, 7th session, Marrakesh. United Nations Framework Convention on Climate Change. Retrieved from: http://ow.ly/Pcf730plEkq

Vashum, K. T., \& Jayakumar, S. (2012). Methods to estimate above-ground biomass and carbon stock in natural forests - A review. Journal of Ecosystem \& Ecography, 02(04). doi: https://doi.org/10.4172/2157-7625.1000116

Waddell, D. R. (1989). Estimating load weights with Huber's Cubic Volume formula: a field trial. Res. Note. PNW-RN-484. Portland, OR: U.S. Department of Agriculture, Forest Service, Pacific Northwest Research Station. 12 p. doi: https://doi.org/10.2737/pnw$\mathrm{rn}-484$

Walkley, A., \& Black, I. (1934). An examination of the Degtjareff method for determining soil organic matter, and a proposed modification of the chromic acid titration method. Soil Science, 37(1), 29-38. doi: https://doi.org/10.1097/00010694-193401000-00003

Wang, X., Wang, J., \& Zhang, J. (2012). Comparisons of Three Methods for Organic and Inorganic Carbon in Calcareous Soils of Northwestern China. PLoS ONE, 7(8), e44334. doi: https://doi.org/10.1371/journal.pone.0044334

West, P. W. (2015). Tree and Forest Measurement. Springer International Publishing. doi: https://doi.org/10.1007/978-3-319-14708-6

Western Australian Planning Commission. (2013). Land use planning in rural areas. State planning policy 2.5. Western Australian Government Gazette, 210. Retrieved from: https://www.slp.wa.gov.au/gazette/gazette.nsf/lookup/2013-210/\$file/gg210.pdf

Williamson, G. B., \& Wiemann, M. C. (2010). Measuring wood specific gravity...Correctly. American Journal of Botany, 97(3), 519-524. doi: https://doi.org/10.3732/ajb.0900243

Xu, Q., Dong, Y., \& Yang, R. (2017). Influence of different geographical factors on carbon sink functions in the Pearl River Delta. Scientific Reports, 7(1). doi: https://doi. org/10.1038/s41598-017-00158-z

Yeboah, D., Burton, A. J., Storer, A. J., \& Opuni-Frimpong, E. (2013). Variation in wood density and carbon content of tropical plantation tree species from Ghana. New Forests, 45(1), 35-52. doi: https://doi.org/10.1007/s11056-013-9390-8

Yin, W., Yin, M., Zhao, L., \& Yang, L. (2012). Research on the Measurement of Carbon Storage in Plantation Tree Trunks Based on the Carbon Storage Dynamic Analysis Method. International Journal of Forestry Research, 2012, 1-10. doi: https://doi. org/10.1155/2012/626149

Zeng, N., King, A. W., Zaitchik, B., Wullschleger, S. D., Gregg, J., Wang, S., \& Kirk-Davidoff, D. (2013). Carbon sequestration via wood harvest and storage: An assessment of its harvest potential. Climatic Change, 118(2), 245-257. doi: https://doi.org/10.1007/ s10584-012-0624-0

Zhang, H., Guan, D., \& Song, M. (2012). Biomass and carbon storage of Eucalyptus and Acacia plantations in the Pearl River Delta, South China. Forest Ecology and Management, 277, 90-97. doi: https://doi.org/10.1016/j.foreco.2012.04.016 